\title{
Dinámica de la confrontación hispano-indígena en el Reino de la Nueva Galicia y regiones adyacentes, siglo $\mathrm{XVI}^{*}$
}

\author{
por \\ Francis Goicovich ${ }^{1}$ \\ Universidad de Chile
}

El objetivo de este trabajo es develar los factores que incidieron en el origen y dilatación de la Guerra Chichimeca que enfrentó a nativos y españoles en la Nueva Galicia durante el siglo XVI. Se propone una clasificación de las acciones españolas, considerando sus intereses y necesidades, y una interpretación del modo en que dichos factores dieron origen a la primera frontera continental del Nuevo Mundo. Las medidas implementadas en este conflicto interétnico fueron un referente en la elaboración y despliegue de políticas fronterizas en otras regiones de América.

Palabras Clave: Guerra Chichimeca; Nueva Galicia; conquista de América; violencia interétnica; fronteras del Nuevo Mundo.

Cómo Citar este artículo / Citation: Goicovich, Francis, «Dinámica de la confrontación hispano-indígena en el Reino de la Nueva Galicia y regiones adyacentes, siglo XVI», Revista de Indias, LXXIX/275 (Madrid, 2019): 9-49. https://doi.org/10.3989/revindias.2019.001.

* Investigación financiada por la International Development Research Fellowship del Social Science Research Council de los Estados Unidos, que me permitió trabajar en archivos de México y España.

Mi agradecimiento a Pablo Cuevas Valdés y Teresa Rojas Martini, alumnos ayer y hoy colegas y amigos, por su generosa acogida en Ciudad de México. A Karin Pereira Contardo y Rodrigo Araya Gómez por su valioso apoyo en mi estancia en Madrid. A Jorge Cañizares-Esguerra, profesor del Departamento de Historia de la Universidad de Texas en Austin, por su orientación. A mi amiga y colega Celia Cussen por su gentil ayuda. A Andrea Rodríguez Silva por sus valiosos comentarios y a Rosa Véliz Morales con eterna gratitud. Un especial reconocimiento a los evaluadores anónimos de este artículo, cuyas observaciones y sugerencias bibliográficas contribuyeron a enriquecerlo.

1 fgoicovi@uchile.cl, ORCID iD: https://orcid.org/0000-0002-3507-3002. 


\section{La Nueva Galicia, el PRIMER laboratorio Fronterizo del Nuevo MUNDO}

Desde los pioneros trabajos de José López-Portillo y Weber ${ }^{2}$ sobre la conquista de la Nueva Galicia, se han experimentado sustanciales avances en el conocimiento del temprano contacto que protagonizaron españoles y chichimecas $^{3}$ en el noroeste de la Nueva España. El historiador norteamericano Philip Wayne Powell tiene el mérito de haber realizado a mediados del siglo XX uno de los aportes más decisivos al incorporar este vasto territorio en el campo de los estudios fronterizos ${ }^{4}$, definiéndolo como la «primera frontera continental ${ }^{5}$. Desde entonces una plétora de investigadores ha corregido y

2 López-Portillo y Weber, 1935; 1939.

3 Las sociedades nativas del norte de México fueron llamadas chichimecas, teochichimecas o teules chichimecas, los «chichimecas auténticos», término heredado de la tradición mesoamericana para referirse a las sociedades del norte que participaban de ciertos usos y costumbres que contrastaban con las propias, como el nomadismo y la atomización política. Los mesoamericanos nombraron a dicha región Chichimecatlalli, la «Tierra de los Chichimecas», o con la más ilustrativa expresión Teotlalpan tlacochcalco mictlampa, aludiendo a un lugar de miseria, dolor, sufrimiento, sed, hambre y muerte. Los ibéricos le llamaron simplemente la «tierra chichimeca», aunque la revistieron con los mismos epítetos despectivos que los habitantes del valle de México. En época reciente se ha consolidado entre los especialistas la expresión "Gran Chichimeca», haciendo alusión a un inmenso territorio que se extendía desde el río Lerma en Guanajuato, hasta el sur de Utah y Colorado en el paralelo $38^{\circ} \mathrm{N}$, abarcando gran parte de lo que hoy conforma el norte de México y el suroeste de los Estados Unidos. Los límites de este espacio geocultural fueron cambiantes a través del tiempo, como bien lo han demostrado los estudios interdisciplinarios. La categoría chichimeca escondía tras un único término clasificatorio a una gran cantidad de sociedades que ni siquiera compartían una lengua común, pero que participaban de costumbres similares. Chantal Cramaussel ha demostrado cuán imprecisas y contradictorias pueden ser las fuentes coloniales en el momento de distinguir y caracterizar a las sociedades nominadas como chichimecas. El principal criterio de clasificación fue el de nación, que incluía a los descendientes de un antepasado común, sin fundarse necesariamente en principios de arraigo territorial. Aplicando un criterio reduccionista, los hombres de la espada y la cruz caracterizaron a los chichimecas con una serie de rasgos opuestos a los atributos del mundo cristiano y de las altas culturas que englobaba el área de influencia de la civilización tolteca. El lenguaje fue una categoría recurrente al momento de clasificar a los naturales, pero que se combinaba con otras variables, como la naturaleza de las relaciones intergrupales (pacíficas o violentas) respecto al hombre blanco. De esta manera, durante el período colonial los factores sobre los que se caracterizó a los chichimecas fueron múltiples y cambiantes en el tiempo, y ello ha impactado en las diversas apreciaciones con que los investigadores los han caracterizado. Sobre este tema, véase Jiménez Moreno, 1944: 128. Armillas, 1969: 697. Di Peso, 1974: 53. Braniff, 1993: 66; 2001: 8. Cramaussel, 2000: 275.

4 Powell, 1975.

5 Powell, 1983: 12. 
perfeccionado estas tempraneras visiones ${ }^{6}$, aportando nuevas perspectivas que van desde los estudios de historia ecológica hasta las propuestas interdisciplinarias, pasando por un amplio abanico de matices intermedios.

A partir de una revaluación de los aportes más recientes sobre la conquista del territorio de la Nueva Galicia, y sustentados en evidencia documental tanto édita como inédita, proponemos una clasificación de los factores que incidieron en el esfuerzo de colonización español en el norte de México. Sostenemos que la intervención hispana se canalizó a través de tres tipos de coerción: la Violencia Corporal, la Violencia Económica y la Violencia Simbólica, cada una de ellas caracterizada por motivaciones, objetivos y procedimientos que las particularizan. Como es de esperarse, las comunidades indígenas afectadas generaron respuestas que iban desde la fuga hasta la contraviolencia, dando pie a una dinámica interétnica que imprimió un sello particular a la frontera norte de la Nueva España. No es nuestra intención hacer un relato histórico de dicho período, numerosos autores clásicos y modernos han elaborado sustanciosas descripciones a las que muy poco se podría agregar. En los párrafos siguientes deseamos profundizar en los factores que dieron vida a la trilogía analítica propuesta, los cuales coadyuvaron al surgimiento y mantención de esa relación de conflicto en el norte de México. Una sistematización de este tipo facilitará los estudios comparativos para futuras investigaciones en otras regiones del continente americano.

Las latitudes septentrionales del territorio mexicano representaron un desafío muy diferente a lo que hasta ese momento había sido incorporado al naciente sistema imperial hispano. Movedizas sociedades de recolectores-cazadores se confabulaban con la escasez relativa de agua y una geografía intrincada, entorpeciendo el accionar de hombres y caballos. Junto a ello, la presencia de sociedades multicéfalas estructuradas sobre las relaciones de parentesco, carentes de líderes nativos con la suficiente autoridad para hacerse obedecer, dificultaba enormemente el proyecto colonizador fundado en el aprovechamiento de la mano de obra local, tal y como había ocurrido en el valle de México. Fue en este espacio aparentemente poco promisorio para la expansión hispana donde se gestó la primera frontera del continente: luchas y alianzas, ambiciones y frustraciones, guerra y paz, política y violencia, y todo un sistema de rearticulaciones y contradicciones dio vida a un ámbito en el que, como nunca antes, el concepto de «indio» fue visto como una real

${ }^{6}$ La etnohistoria y la arqueología han demostrado que ya existía una relación fronteriza entre las culturas mesoamericanas y las culturas del desierto en el norte de México mucho antes del arribo español. Véase Kirchoff, 1943: 92-107; 1944: 133-144. Braniff, 1974: 40-50. Nárez, 2000: 121-157. Hers, 2001: 65-70. Beals, 2011: 51. Levin Rojo, 2014: 41-50. 
amenaza. Posteriores contextos fronterizos, como el mapuche en el sur de Chile, el guaraní en el Río de la Plata, o el guaycurú en la región del Chaco, a pesar de las particularidades que los individualizan, participaron de dinámicas de interacción similares con el hombre blanco. Más aún, experiencias gestadas en el norte de la Nueva España fueron un referente para la implementación de políticas de control en esas regiones apartadas.

\section{VIOLENCIA CORPORAL: CASTIGO FÍSICO, MUTILACIONES Y ESCLAVITUD}

Trabajos históricos recientes, escritos principalmente por intelectuales indígenas de todos los rincones del continente americano, han puesto en un lugar central el rol del dolor, el ultraje y la vejación para la comprensión de la relación histórica entre las sociedades nativas y el hombre blanco. Inspirados por el afán de denunciar un pasado traumático y desolador sobre el que se levanta la precaria situación de su presente, libros como Violence over the land de Ned Blackhawk ${ }^{7}$ o ; ...Escucha, winka...! de Pablo Marimán et alii ${ }^{8}$, son un intento reivindicatorio por denunciar las penurias que emanaron de esta forzada interacción en distintas etapas de la historia. A pesar de que el Caribe y el núcleo mesoamericano fueron las primeras áreas culturales nativas en experimentar el impacto de una relación fundada sobre la amenaza y la violencia de los europeos, habrían de ser los espacios fronterizos los escenarios en que se protagonizarían los conflictos más dilatados y enérgicos, y el noroeste de México fue el primero de todos en el Nuevo Mundo.

La expedición de Nuño Beltrán de Guzmán marcó el comienzo de la controvertida relación interétnica en Nueva Galicia. Como un preámbulo de lo que sucedería en otras regiones del continente, la entrada que inició en diciembre de 1529 con una hueste de «ciento y cincuenta de caballo y otros tantos peones, bien armados, y con doce piezas de artillería menuda y con siete ó ocho mil indios amigos y proveídos de todo bastimento» ${ }^{9}$, ha quedado en la historia como uno de los episodios más cruentos de la conquista del Nuevo Mundo. La ferocidad desplegada por los españoles y sus aliados mexicas y tlaxcaltecas caló tan hondo en la conciencia del dominico fray Bartolomé de Las Casas, que dedicó un capítulo de su Breve relación de la destruc-

7 Blackhawk, 2006.

8 Marimán, Caniuqueo, Millalén y Levil, 2006.

9 Carta a S.M. del Presidente de la Audiencia de Méjico, Nuño de Guzmán, en que refiere la jornada que hizo a Mechoacan, a conquistar la provincia de los Tebles Chichimecas que confina con Nueva España, 1530, en Razo Zaragoza, 1963: 25. 
ción de las Indias Occidentales para denunciar las atrocidades cometidas ${ }^{10}$. Las historiografías tradicional y contemporánea han erigido un juicio lapidario de esta intervención desmedida, llegando al consenso de que esta campaña por sí sola «explica el continuo odio que antepusieron los indios de la frontera a los españoles» ${ }^{11}$. Los expedicionarios echaron mano de todo cuanto estuvo a su alcance para saciar sus ansias de riqueza y estatus social, pues como bien señala Francisco Román Gutiérrez, la entrada de Nuño Beltrán de Guzmán «fue la primera oportunidad para todos aquellos que llegaron después de la conquista de Tenochtitlán y no formaron parte de la hueste de Hernán Cortés surgida en las expediciones hacia el occidente y sur de México» ${ }^{12}$. Los conatos de resistencia fueron ahogados a punta de espada, procurando sofocar cualquier tentativa de reincidencia por medio de penas extremas que sirvieran de escarmiento. En la región de Jalisco fueron capturados dos líderes nativos que alentaban la rebelión, debiendo pagar su obstinación con la mutilación de «las manos y narices» ${ }^{13}$, y algunas décadas después Francisco Tenamaztle, cacique de las provincias de Nochistlán y Jalisco, denunció al rey los agravios de que había sido objeto, viviendo desterrado al ser despojado de su señorío, «padeciendo muchas injurias y afrentas y persecuciones» ${ }^{14}$.

La esclavitud forzada y compulsiva, apoyada en una violencia desmedida, fue lo que dejó el testimonio más claro y perenne de la naturaleza brutal de la primera expedición conquistadora al corazón de la Nueva Galicia. Las primeras víctimas fueron los tarascos oriundos de Michoacán, quienes se vieron forzados a apoyar la marcha hacia el norte con cargadores o tamemes,

10 Las Casas, 1957: 99. Apenas tres años después de la aparición de este trabajo fue impreso el célebre reporte de Núñez Cabeza de Vaca, 1922, en que testifica los horrores y destrucción causados por la hueste de Nuño Beltrán de Guzmán. Véase también Adorno, 1994: 75-86.

11 Assadourian, 2008: 29. Francisco Vázquez de Coronado, apenas asumió la gobernación de la Nueva Galicia por disposición del virrey Antonio de Mendoza, comprobó que «la mayor parte de los indios del Nuevo Reino de Galicia estaba de guerra, así por no se haber conquistado algunos como los otros por malos tratamientos causados de las necesidades de los conquistadores»; véase Herrera, 1953, década VI, libro V, cap. 9: 412.

12 Román Gutiérrez, 1993: 359.

13 Relación del descubrimiento y conquista que se hizo por el gobernador Nuño de Guzmán y su ejército en las provincias de la Nueva Galicia, escrita por Gonzalo López y autorizada por Alonso de Matta, escribano de su Majestad, 1530, en Razo Zaragoza, 1963: 78. Véase también en la misma obra la relación de Pedro de Carranza: 164.

14 Tenamaztle, 1959: 11. Entre las numerosas ilustraciones que componen el Lienzo de Tlaxcala hay una que representa el combate que sostuvieron los chichimecas de Jalisco y los tlaxcaltecas que acompañaban la expedición de Nuño Beltrán de Guzmán; véase Chavero, 1979: 53. 
siendo muchos de ellos «repartidos por los españoles, y echados algunos en cadenas, llevando las petacas a cuestas $\rangle^{15}$. A pesar de estas medidas las fugas fueron inevitables, lo que junto a las enfermedades y los maltratos mermaron el número de indios auxiliares. Así, se recurrió al apoyo de las poblaciones que se iban descubriendo, incorporando a nuevos tamemes con el argumento de la convicción o la amenaza sin la menor consideración por mujeres y niños: la enconada resistencia de los nativos de Cacocalpa y Naguatlán fue la excusa perfecta para que Nuño Beltrán de Guzmán les hiciese guerra a fuego y sangre, condenando a los apresados a que se «los herrase por tales esclavos» ${ }^{16}$; los nativos de Jalisco, creyendo en las promesas de paz y amistad, «por engaño fueron metidos é presos» ${ }^{17}$ en un gran corral, acontecimiento en que el capitán Gonzalo López, en una declaración posterior, se jactó «de haber hecho mucha presa de gente, hombres y mugeres, y niños [...] que así se herraron hasta mil esclavos» ${ }^{18}$.

Aunque los defensores de los derechos indígenas, tanto dentro como fuera de la Nueva España, hicieron un juicio severo de la expedición de Nuño Beltrán de Guzmán, a quien acusaron de poner «toda aquella tierra en la ordinaria y pestilencial servidumbre tiránica, [en la] que todos los tiranos cristianos de las Indias suelen y pretenden poner aquellas gentes» ${ }^{19}$, el conquistador español actuó convencido de que sus acciones iban en directo beneficio de la Corona. Cuando Carlos V expidió la Real Provisión de 2 de agosto de $1530^{20}$, prohibiendo la servidumbre de los indios aun en los casos de guerra justa, Beltrán de Guzmán manifestó su molestia argumentando que la Nueva Galicia era un territorio de difícil asentamiento y comunicación por la hostilidad de los naturales, por lo que la esclavitud tenía el doble mérito de ser el medio más eficaz para someter a los rebeldes, y una compensación a las pe-

15 Relación de la entrada de Nuño de Guzmán a Nueva Galicia que dio García del Pilar, su intérprete en la jornada, sf., en Razo Zaragoza, 1963: 218-219.

16 Relación del descubrimiento y conquista que se hizo por el gobernador Nuño de Guzmán y su ejército en las provincias de la Nueva Galicia, escrita por Gonzalo López y autorizada por Alonso de Matta, escribano de su Majestad, 1530, en Ibidem: 88.

17 Relación de la entrada de Nuño de Guzmán a Nueva Galicia que dio García del Pilar, su intérprete en la jornada, sf., en Ibidem: 230.

18 Relación del descubrimiento y conquista que se hizo por el gobernador Nuño de Guzmán y su ejército en las provincias de la Nueva Galicia, escrita por Gonzalo López y autorizada por Alonso de Matta, escribano de su Majestad, 1530, en Ibidem: 111.

19 Las Casas, 1957: 99-100.

20 Real Provisión que no se pueda cautivar, ni hacer esclavo a ningún indio, Madrid, 2 de agosto de 1530, en Konetzke, 1953: 134-136. Tello, 1997, cap. LIX: 177. Esta provisión fue precedida de una cédula del 12 de julio de 1530, según consta en el Cedulario de 1574 compuesto por Zorita, 1985: 27. Véase también Zavala, 1967: 30. 
nurias y privaciones sufridas por los conquistadores, quienes arriesgaban sus vidas en favor de la monarquía y grandeza de España ${ }^{21}$.

En un comienzo, el impulso descubridor de los conquistadores que partían al norte de la Nueva España fue alimentado por el ansia de hallar ciudades fantásticas como Quivirá, las Siete Ciudades de Cíbola, o el poblado de Las Amazonas $^{22}$. Las expediciones pioneras de Francisco Cortés de Buenaventura en 1524-25, Nuño Beltrán de Guzmán en 1529-31, Fray Marcos de Niza en 1538, Francisco Vázquez de Coronado en 1540-42, y Francisco de Ibarra en 1564-65, estuvieron inspiradas en buena medida por estas aspiraciones ${ }^{23}$. Pero al cabo de unas cuantas décadas el descubrimiento sistemático de vetas argentíferas desencadenó una fuerte corriente migratoria que desafió las barreras geográficas y el peligro de los ataques indios 24 ; François Chevalier, en un sucinto pero ilustrativo pasaje, afirma que «los reales de minas vinieron a constituir la osamenta de la colonización en las provincias septentrionales, de tal manera que la vertiente del golfo, donde no se encontraron minas, quedó sin colonizar hasta fines del siglo XVII y aún hasta el XVIII» ${ }^{25}$. El golpe maestro ocurrió en septiembre de 1546, cuando Juanes de Tolosa descubrió las minas de Zacatecas. Pocos años transcurrieron para que quedara en evidencia que el interés económico de los mineros fue más poderoso que el temor a las acometidas chichimecas ${ }^{26}$; la aguda pluma del obispo Pedro Gómez de Maraver ilustra esta situación:

Con el descubrimiento de las minas esta provincia se yva engrandeciendo poblando y ennobleciendo y esta cibdad de guadalaxara y todo el reyno ansi de españoles como de naturales por las contrataciones e aprovechamientos de ellas e yba tan encaminado e crecia tan de golpe que en breve tiempo se tuvo entendido fuera provincia muy rica y principal en estas partes ${ }^{27}$.

${ }^{21}$ Carta a la Emperatriz de Nuño de Guzmán, dando cuenta del estado en que se hallaba la conquista y población de la Nueva Galicia, y quejándose de los daños que le hacian la Audiencia y el Marqués del Valle, Compostela, 12 de junio de 1532, en Paso y Troncoso, 1939: 146-147.

22 Para entender el rol de la literatura medieval y renacentista en la mentalidad de los conquistadores de América, véase el trabajo clásico de Leonard, 1949. Sobre el mito de las Amazonas en la exploración del norte de México, Leonard, 1944.

${ }_{23}$ Una buena síntesis de estas expediciones en Sauer, 1998, especialmente el cap. IV, «La ruta de Cíbola»: 247-316.

${ }^{24}$ Sobre la expansión española en territorio chichimeca, véase el trabajo de Cisneros Guerrero, 1998: 57-70.

25 Chevalier, 1999: 121.

26 «Zacatecas en 1550», en Sescosse, 1960: 4-9.

27 Interesante relación del Ilustrísimo Señor Maraver al Rey de España, Guadalajara, 12 de diciembre de 1550, en Orozco y Jiménez, 1922: 216-217. Thomas Calvo afirma que du- 
La vorágine minera requirió de un suministro constante de recursos que permitiesen su sustento. Alimentar y vestir a un número ascendente de españoles, mestizos, negros e indígenas significó un verdadero desafío. Si bien México y Michoacán fueron las primeras fuentes de abastecimiento, las distancias extremas, el mal estado de las rutas, el alto costo de los fletes y el hostigamiento de los indios demandaban un flujo más cercano y expedito de bienes. En la medida que la producción argentífera de la Nueva Galicia fue despertando un creciente interés para la Corona y los funcionarios reales asentados en la capital virreinal, se hizo cada vez más imperiosa la necesidad de controlar a las tribus nativas para así proceder a la erección de centros poblados que proveyeran la mano de obra encargada de la explotación de los filones, así como de estancias agrícola-ganaderas que proporcionasen los recursos para su sustento a un costo menor que la importación desde los grandes centros hispanos meridionales. El levantamiento y desarrollo espontáneo de estos asentamientos fue respaldado pocas décadas más tarde por una legislación que pretendía apaciguar el ánimo de los nativos, conminándolos a que «se recojan a vivir en pueblos políticamente» ${ }^{28}$, donde serían instruidos en los misterios de la fe, apartándolos de la costumbre de «asaltar y robar y matar por los caminos a los españoles e indios que están de paz» ${ }^{29}$. En la concepción europea el hombre-salvaje estaba condicionado por el ambiente hostil en que se desenvolvía, moldeado en su mentalidad por la dureza de su modo de vida y carencia de razón, pero esta condición podía ser rectificada mediante la aculturación $^{30}$. Con esto, la Corona no hacía más que proseguir con una política de civilización en el sentido romano de civitas, vale decir, la personificación de la sociedad en la ciudad ${ }^{31}$, centro de todas las transformaciones y de todas las virtudes. El historiador Jaime González Rodríguez ha demostrado que desde el inicio de la expansión ibérica en el Nuevo Mundo, el naciente Imperio Español se proclamó como un ente civilizador del continente recién descubierto en la misma forma que Roma civilizó al Viejo Mundo ${ }^{32}$. La Nueva Galicia no

rante la segunda mitad del siglo XVI la ciudad de Guadalajara, que desde 1560 desplazó a Compostela como capital de la Nueva Galicia, se había convertido en un puente para los migrantes a Zacatecas, centro minero que crecía exponencialmente mientras aquélla mantuvo una demografía casi sin variaciones; véase Calvo, 1989: 20-21.

28 Real Cédula para que los indios de la Nueva Galicia vivan en pueblos y congregados, El Escorial, 4 de noviembre de 1568, en Enciso Contreras, 1998: 239.

${ }^{29}$ Real Cédula para que los indios de la Nueva Galicia se junten en pueblos y vivan en policía, El Carpio, 26 de mayo de 1570, en Ibidem: 261-262.

30 Colin, 1999: 7-8.

31 McEnroe, 2014: 30.

32 González Rodríguez, 1981. 
fue el primero ni tampoco habría de ser el último eslabón de esta cadena de transformaciones.

La demanda progresiva de bienes generada por una igualmente creciente población inmigrante fue la semilla de un sistema de economías de escala en el cual una serie de estancias agrícolas y ganaderas fueron surgiendo en forma espontánea y acelerada, muy especialmente en las regiones más fértiles del meridión de la Nueva Galicia y al oriente de Guadalajara, conocidas como El Bajío $^{33}$. Como bien destaca Miguel Othón de Mendizábal, la colonización de los diferentes yacimientos fue una acción total, es decir minera, agrícola, ganadera y forestal ${ }^{34}$. La villa de San Miguel fue fundada en 1555, el mismo año se levantó el pueblo de Pénjamo en el límite de la Nueva Galicia como «frontera y defensa contra los indios chichimecas» ${ }^{35}$, San Luis de Xilotepec surgió en 1560, San Felipe en 1562 para amparar a los chichimecas pacíficos de Xichú, Santa María de los Lagos en 1563, Sila y Nuestra Señora de la Concepción de Celaya en 1571, Asunción de Aguascalientes en 1575, y León en 1576. Más al norte se levantaron Nombre de Dios y Durango en 1563, y Jerez de la Frontera al oriente de Zacatecas en 1570. Aunque muchos de estos poblados defensivos estuvieron numerosas veces al borde de desaparecer, en el largo plazo fueron fundamentales para la pacificación de la región norteña, ya que además de su función militar «estimularon el desarrollo agrícola, mantuvieron vivos los caminos, permitieron el establecimiento de indios ya pacificados, sirvieron como imán para los chichimecas en guerra y, en resumen, resultaron la mejor base para que la fuerza de españoles e indios sedentarios lograra imponer el orden en la tierra de los chichimecas» ${ }^{36}$.

En la erección de estas poblaciones se contó con el apoyo de mexicas del valle de México, tarascos de Michoacán, y muy especialmente de otomíes venidos de la región de Querétaro, quienes recibieron privilegios especiales como la entrega de bueyes y arados para trabajar la tierra, la excención de tributos por dieciséis años ${ }^{37}$, y los caciques títulos nobiliarios en compensación por llevar a sus súbditos a la tierra de guerra ${ }^{38}$.

33 Véase Wright-Carr, 1999, especialmente el cap. 3: «La colonización del Bajío durante el siglo XVI»: 36-65.

34 Othón de Mendizábal, 1944: 44. Powell, 1950: 238.

35 Carrillo Cázares, 2006, en especial el documento Petición de congregación en el pueblo de Pénjamo, México, 17 de enero de 1601: 131.

36 Gómez Serrano, 2001: 77.

37 Lo que Vuestra Señoría en nombre de Su Majestad concede a los indios de Xilotepeque que se han de poblar en el camino real de los Çacatecas en un sitio adelante de San Miguel, México, 29 de mayo de 1560, en Powell, 1971: 83.

38 Véanse los documentos publicados por Wright-Carr, 1988. También Cruz Rangel, 2003: 203. 
Plano 1. Del pueblo de Ameca, jurisdicción de la Audiencia de

GuAdAlaJARA, CONFECCIONADO HACIA 1579. EN SUS CONTORNOS SE DISTINGUEN UNA ESTANCIA DE ASNOS, UNA DE PUERCOS, UNA DE OVEJAS Y UNA DE GANADO MAYOR, DESTINADAS A ABASTECER LAS REGIONES MINERAS

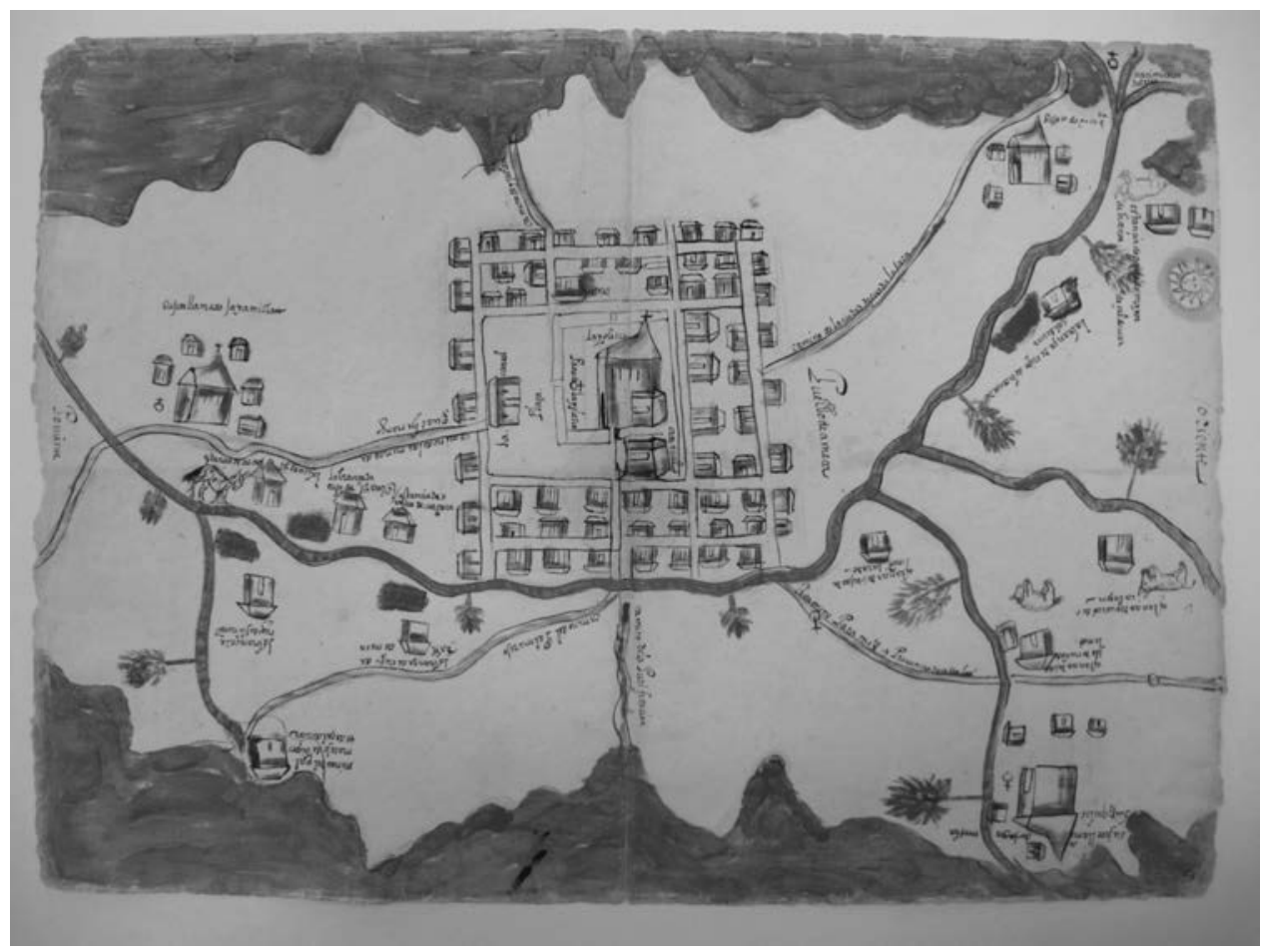

Gentileza Nettie Lee Benson Library, Sección Libros Raros y Manuscritos, University of Texas at Austin.

Mantener el tráfico de suministros y mano de obra hacia la región minera, así como el flujo de plata hacia México, requirió la apertura de una ruta que fue conocida con el nombre de Camino Real de la Tierra Adentro ${ }^{39}$, además de una serie de vías secundarias y senderos que unían a las estancias con los centros de explotación. Alfredo Jiménez, haciendo gala de una refinada pluma,

39 Bakewell, 1971: 19. El virrey saliente, Antonio de Mendoza, recomendó a su sucesor Luis de Velasco que fuese aderezado el camino de Zacatecas «para que puedan ir y venir por él arrias», véase la Relación, apuntamientos y avisos que por mandado de Su Majestad el virrey don Antonio de Mendoza dio al señor don Luis de Velasco, visorrey y gobernador y Capitán General de esta Nueva España, México, s/f (¿1550?), en Torre Villar y Navarro de Anda, 1991: 112. 
grafica esta situación diciendo que «no había caminos que llevaran a las minas, sino que las minas creaban los caminos $\rangle^{40}$. La construcción de la principal ruta de penetración al altiplano septentrional recayó en los mineros, quienes aprovecharon de grado o por fuerza la mano de obra aborigen local para empedrar un sendero usado inicialmente por los tamemes, dejándolo apto para el tránsito de carretas tiradas por bueyes, mucho más eficientes en el traslado de las voluminosas cargas de bienes que abastecían a los poblados del norte ${ }^{41}$. En la construcción de esta ruta gravitó la fuerte tradición europea de abrir corredores militares para la circulación de tropas y pertrechos con el propósito de integrar más eficientemente la administración central con las regiones más apartadas de los reinos, vías que en el caso español solían conocerse como «rutas reales» ${ }^{42}$.

El hallazgo de nuevos filones, conforme se avanzaba hacia el norte, hacía imperecedero el establecimiento de estancias que fueron salpicando por los apartados rincones del territorio. La dificultad para el abastecimiento desde la capital virreinal significó que los distritos mineros fronterizos se vieran en la obligación de encontrar y explotar muchos suministros localmente, como «cueros para transportar el mineral, sebo para iluminar los túneles, y carne, queso, leche y productos agrícolas para mantener a los mineros y sus mulas, [lo cual demuestra que] una frontera agraria iba detrás de la frontera minera a medida que se deslizaba a través del fragmentado norte» ${ }^{43}$. Alcanzar la autonomía económica fue, sin embargo, un ideal contra el que complotaban las características agrestes del medio, las escasas y localizadas porciones suficientemente fértiles del territorio, así como las embestidas imprevisibles de los nativos, por lo que era imprescindible mantener el flujo de hombres y bienes proveniente de México y Michoacán.

Sin embargo, la red de abastecimiento soportó a duras penas la amenaza constante de las incursiones chichimecas, quienes solían descolgarse desde las tierras altas y quebradas circundantes para asolar las minas, haciendas y caravanas que sostenían la economía de la Nueva Galicia. En carta al rey de 1551 el oidor Hernán Martínez de la Marcha informó de los daños que los zacatecos y guachichiles hacían «a las recuas que pasaban para llevar bastimentos a las dichas minas» ${ }^{44}$. Poco más de una década después una rebelión indígena fue causa de grandes pérdidas económicas «por aver cesado mucha parte del bene-

40 Jiménez, 2006: 330.

41 Cramaussel, 2007: 301-302.

42 Sobre este punto, véanse los trabajos de Parker, 1972; 2002.

43 Sheridan, 1992: 160.

44 Carta del oidor Hernando Martínez de la Marcha a Su Majestad, Compostela, 18 de febrero de 1551, en Assadourian, 2008: 252. 
ficio de la plata por la carestía e falta de bastimentos e cosas necesarias», pasando las minas de Zacatecas grandes apuros porque «cesó dentrar en ellas los bastimentos de suerte que muchos de los pobladores dellas las desampararon ${ }^{45}$. Como éstos, fueron muchos los reportes de décadas posteriores que atribuían a los chichimecas la inseguridad de las rutas y comarcas septentrionales, así como también las fluctuaciones en la producción minera.

Mapa 1. De la Nueva Galicia y Regiones CiRCundantes en la SEgunda MITAD DEL SIGLO XVI. SE DESTACAN LOS TERRITORIOS EN QUE SE DESENVOLVÍAN LAS PRINCIPALES SOCIEDADES NATIVAS EN TORNO A LA RUTA MÉXICO-ZACATECAS, Y ALGUNOS DE LOS PRESIDIOS QUE LA RESGUARDABAN DE LOS ASALTOS CHICHIMECAS

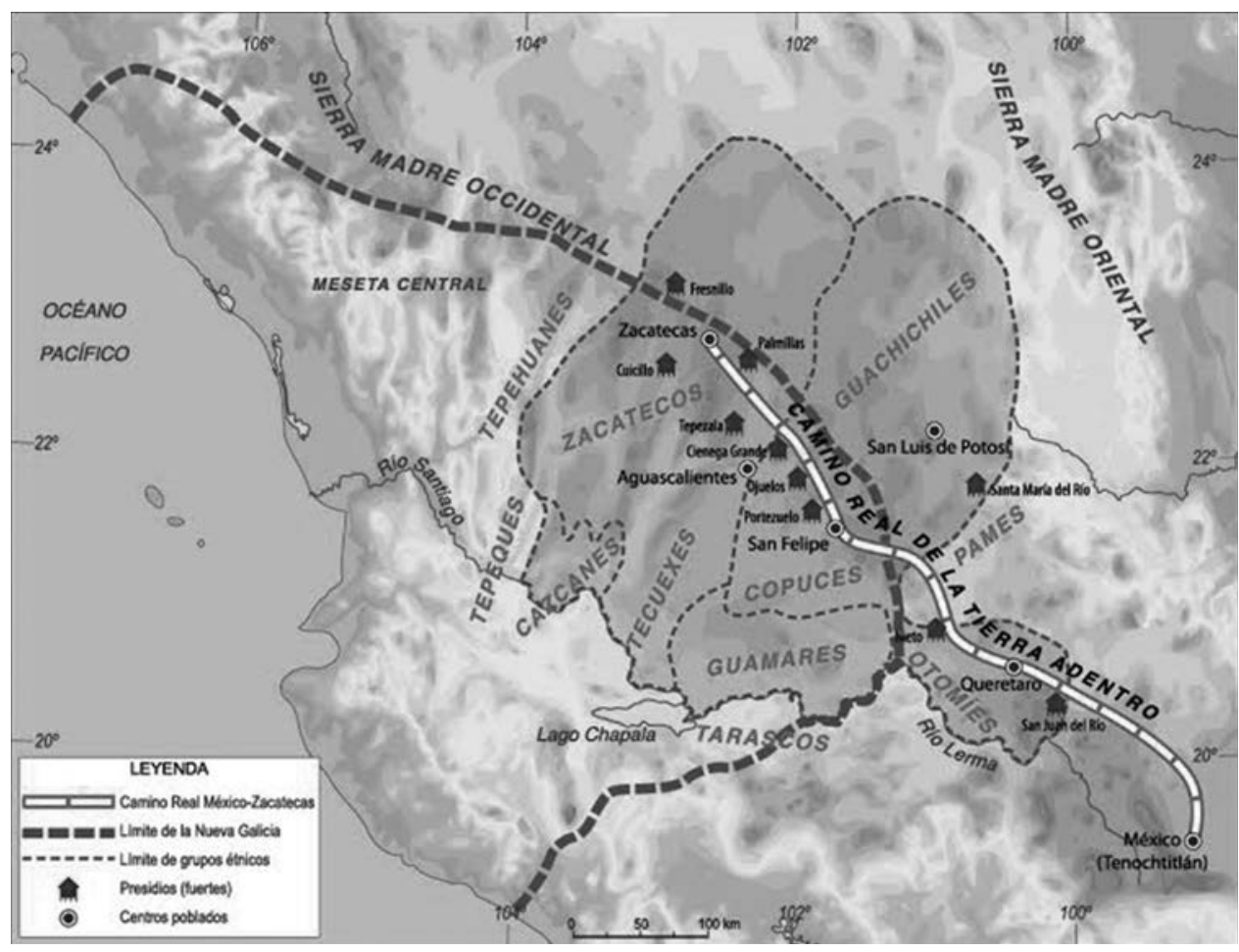

Cartografía de José Compan Rodríguez.

45 Información acerca de la rebelión de los indios zacatecas y guachichiles a pedimento de Pedro de Ahumada Sámano: Interrogatorio, minas de Zacatecas, 24 de enero de 1562, en Montoto, 1927: 250, 251. 
Los chichimecas de la Nueva Galicia fueron los primeros nativos del continente en desarrollar una cultura ecuestre ${ }^{46}$, y los españoles fueron en gran medida los responsables de esto. Aunque existe constancia de la presencia de caballos cimarrones en las regiones del norte hacia la década de 1540, fue en el decenio siguiente que el virrey Luis de Velasco I ordenó el traslado del ganado mayor que se concentraba en las densamente pobladas regiones centrales de la Nueva España hacia el área septentrional, todo esto en un intento por resguardar las tierras agrícolas y los suministros de alimentos de indios y españoles que usualmente eran dañados por el pastoreo de las bestias ${ }^{47}$. La historiografía fronteriza ha demostrado que diversos grupos nómadas y seminómadas del continente supieron sacar provecho de este animal usándolo como fuente de carne y medio de transporte para sus circuitos de movilidad e incursiones predatorias ${ }^{48}$. David Weber, en un ya clásico trabajo, destacó que gracias al caballo tanto la economía como el accionar bélico de los nativos se potenciaron a niveles nunca antes vistos, ya que por un lado se hicieron cazadores más eficientes, y por otro tenían la posibilidad de incursionar más profundamente en territorio enemigo escapando raudamente con un botín mayor en especies, mujeres y niños, todo lo cual contribuyó a intensificar tanto los conflictos intertribales como el enfrentamiento con el hombre blanco ${ }^{49}$. Del mismo modo, el caballo también permitió incrementar el número de involucrados en las correrías indígenas. La velocidad de los corceles facilitaba la conformación de alianzas con diversas agrupaciones repartidas en la inmensa geografía del norte, dando pie a la articulación de nuevos mecanismos de cooperación social llegando incluso a la fusión de bandas dispersas. Estas alianzas, que podían ser permanentes, estacionales o circunstanciales, hicieron más eficiente la defensa de los naturales y más arriesgado el tránsito de los españoles por las intrincadas rutas del norte.

En efecto, las incursiones chichimecas se hicieron más frecuentes y dinámicas con la incorporación definitiva del caballo a fines de la década de $1550^{50}$. Una vez dominado este medio de transporte, los asaltos a minas, villas y haciendas se llevaron adelante bajo la modalidad del golpe-y-fuga, mientras

46 Lázaro Ávila, 1997: 60-61.

47 Melville, 1997: 24.

48 Jones, 1998: 99.

49 Weber, 2005: 80.

50 Barral Gómez, 1992: 99, sostiene que la incorporación del caballo por los nativos del norte data de los días de la Guerra del Mixtón. Aunque no deja de ser cierto, no será hasta la segunda mitad del decenio de 1550 que los rebeldes masifiquen la doma de este animal. 
que las caravanas eran emboscadas ${ }^{51}$, alcanzando las correrías un rango de cobertura más amplio que la movilidad pedestre. El capitán Pedro de Ahumada refirió que en la rebelión zacateco de 1561 desbarató una partida de indios en la región de las minas de Avino, tomándoles más de doscientos caballos ${ }^{52}$, lo que da cuenta de cuán numerosas podían ser las cuadrillas ecuestres.

Las medidas adoptadas para hacer frente al problema de los hostigamientos de los rebeldes en las comunicaciones iban desde la organización de tropas de escolta para caravanas de carretas, hasta la construcción de refugios ( $c a$ safuerte), especialmente diseñados y reforzados para resistir ataques ${ }^{53}$. El afán por contrarrestar los asaltos incluso inspiró la invención de ingenios defensivos móviles, los carromatos, más resistentes que las tradicionales carretas tiradas por bueyes ${ }^{54}$.

El exiguo apoyo del gobierno hacía que el mayor peso de la defensa cargara sobre las espaldas de los privados, los más directos afectados ${ }^{55}$. La Corona dispuso por Real Cédula de 20 de abril de 1567 que la audiencia de Nueva Galicia tomara medidas para proteger a los mineros y las vías de comunicación, pero que dos tercios del coste de las operaciones fuera pagado por los propios colonos, contribuyendo la Real Hacienda apenas con una tercera parte ${ }^{56}$. La monarquía siempre manifestó una escasa disposición a financiar las operaciones contra los indios, dejando esa costosa tarea en manos de los particulares hasta donde fuese posible. Solo bien avanzada la segunda mitad del siglo XVI se dispuso la implementación de un ejército profesional encabezado por un alcalde mayor, quien cumplía la función de capitán gene$\mathrm{ral}^{57}$, y el establecimiento de presidios dispuestos en puntos estratégicos de la tierra de guerra, táctica concebida en el gobierno del virrey Luis de Velasco I (1551-1564) y materializada por el virrey Martín Enríquez de Almanza

51 Powell, 1945: 334.

52 Información acerca de la rebelión de los indios zacatecas y guachichiles a pedimento de Pedro de Ahumada Sámano: Interrogatorio, minas de Zacatecas, 24 de enero de 1562, en Montoto, 1927: 257.

53 Powell, 1982: 129.

54 Powell, 1950: 239.

55 Powell, 1944b: 597.

56 Real Cédula para que se resguarden las minas y caminos de la Nueva Galicia, Madrid, 20 de abril de 1567, Archivo General de la Nación, México (en adelante AGNM), Reales Cédulas Duplicadas, legajo 47, f. 588.

57 Nombramiento e instrucciones dadas a Pedro de Gomar Reynoso como capitán contra los Chichimecas en la región de Comanja-León, 1576-1577, en Powell, 1971: 195-199. Real Cédula para levantar un cuerpo de soldados a costa del rey, Badajoz, 10 de junio de 1580, en Enciso Contreras, 1998: 460-461. 
(1568-1580), quien impulsó una «guerra a fuego y sangre» para sofocar los ataques chichimecas ${ }^{58}$. La función de estas guarniciones militares era la protección de caminos y poblaciones, así como también la de «abrir campo, empujando a las tribus hacia el norte y liberando amplios espacios para el cultivo y la crianza» ${ }^{59}$. Algunos fueron destinados a la protección de los asentamientos misionales, otros a amparar los reales de minas, y la amplia mayoría a asegurar la comunicación de la ruta México-Zacatecas, actuando como enclaves de refugio, centros de abastecimiento y lugares de descanso para los viandantes. Philip Wayne Powell calcula en 57 el número de presidios levantados entre 1570 y 1600 en el territorio chichimeca ${ }^{60}$.

Sin embargo, el proyecto siempre tropezó con el problema de la falta de recursos. El bajo salario, que en días de la administración de Enríquez apenas ascendía a 300 pesos o menos al año, además de la falta de pólvora ${ }^{61}$ y equipamiento militar ${ }^{62}$, generó que las deserciones de los soldados fueran frecuentes $^{63}$, muchos de los cuales eran convictos que optaban por cumplir sus condenas en los fuertes fronterizos ${ }^{64}$, por lo que la indisciplina era un inconveniente habitual. Además, la difícil situación de muchas haciendas cercanas impedía el abastecimiento de alimentos, como ocurrió con el presidio de Aguascalientes cercano a la villa de Nuestra Señora de la Asunción, con la cual era imposible mantener «ninguna contratación ni valerse de sementeras, porque no dan lugar los indios chichimecas de guerra, que los matan y les hurtan los caballos y bueyes que tienen en cualquier parte del año» ${ }^{65}$.

El tiempo y las circunstancias demostraron que el sistema de presidios era un recurso excesivamente costoso de mantener y de dudosa efectividad ${ }^{66}$.

58 Una excelente aproximación a las medidas implementadas y personalidad de este virrey en Powell, 1957: 1-24.

59 Arnal, 2010: 110.

60 Powell, 1982: 133-134 (nota 18). Sobre el desarrollo del sistema de fuertes en territorio chichimeca véase también Powell, 1944a: 179-200.

${ }^{61}$ Informe sobre la situación de los fuertes y minas de la frontera chichimeca, México, 7 de mayo de 1587, Archivo General de Indias, Sevilla (en adelante AGI), México, 324.

62 Powell, 1944b: 593-594.

${ }^{63}$ Nombramiento dado a Martín de Pedraza, escribano, para las causas que se forman contra los soldados que se ausenten para no pelear contra los indios chichimecas, San Luis Potosí, 1582, AGNM, Indios, 2, exp. 206, f. 53v.

${ }^{64}$ Solicitud de Bernardino Jiménez para que se le permita cumplir su castigo en un fuerte de los chichimecas, 1 de junio de 1583, AGNM, Indios, 2, exp. 856, f. 195v.

65 Relación del pueblo de Teucaltiche por Hernando de Gallegos, Teucaltiche, 30 de diciembre de 1584, en Acuña, 1988: 303.

66 Faulk hizo una evaluación global del sistema de presidios como dispositivo de conquista en la frontera norte, llegando a la conclusión de que «fue incapaz de detener las incur- 
A los pocos años de su instauración el licenciado Alonso Martínez hizo patentes sus limitaciones destacando que los fuertes y villas no eran una solución eficaz porque «la tierra donde los salteadores habitan es muy larga y sus guaridas inexpugnables» ${ }^{67}$. Algunos años después el virrey Lorenzo Suárez de Mendoza, Conde de Coruña, representó al rey Felipe II la dificultad de controlar un extenso territorio contando con pocos soldados e insuficientes recursos, «porque es bastante la distancia de ella por donde ellos [los chichimecas] pueden entrar, que es imposible asegurarla toda si no es con gran ejército de gente y gastos excesivos» ${ }^{68}$. Hacia 1586 , basado en éste y otros informes despachados desde la Nueva España, el mismísimo rey sentenció que «asegurar los caminos con presidios de soldados no se tiene por buen remedio» ${ }^{69}$.

Hasta entonces las carencias en las fortalezas eran parcialmente solventadas mediante el saqueo de las sementeras de algunos grupos seminómadas o incluso de aliados reducidos ${ }^{70}$, y más frecuentemente con las ganancias derivadas de la esclavitud de los indios, sin importar si se trataba de nativos rebeldes o grupos pacificados. Juan Alonso Velázquez, clérigo de la villa de San Miguel, elevó la voz para acusar a los capitanes que engañaban a los indios con el propósito de secuestrarlos «debajo de seguro y aun dentro en las iglesias en pueblos de paz», llegando al extremo de esclavizar a los indios amigos que los secundaban en las campañas; más aún, algunos líderes militares tenían la costumbre de desviar sus expediciones punitivas a tierras «más adentro en

siones de los indígenas hacia el interior de la Nueva España. Sirvió como refugio durante las incursiones para civiles y soldados, pero en raras ocasiones sirvió como zona segura capaz de organizar campañas eficaces contra los acechantes nativos. Como arma de defensa, fue fortaleza, como arma ofensiva, casi siempre fue una farsa»; véase Faulk, 1976: 67.

${ }^{67}$ Fragmento de carta del licenciado Alonso Martínez a Juan de Ovando, Presidente del Consejo de Indias, 1576, en Assadourian, 2008: 423.

68 El Conde de Coruña, virrey de Nueva España, da cuenta al rey de asuntos muy diversos del virreinato, México, 12 de abril de 1583, Archivo General de Indias, Sevilla (AGI), México, 20.

${ }^{69}$ Al Virrey de la Nueva España que embie relacion con su parecer sobre que se ha avisado que para reducir y pacificar los Yndios Chichimecas convernia usar de los medios que aqui se rrefieren fundando en su comarca pueblos y monasterios, Sant Lorenço, 19 de junio de 1586, en Hackett, 1923: 154. La transcripción registra erradamente el año 1566.

${ }^{70}$ Alonso López, vecino de la villa de San Felipe, testificó el 22 de febrero de 1582 que «los dichos soldados como [h]an sido mal pagados algunos dellos [h] hen hecho agravios a los indios de los pueblos de paz quytándoles [sic] sus comidas y otras cosas por no se poder sustentar cómodamente», véase la Petición ante el Virrey de los criadores de ganados, vecinos y moradores de la frontera Chichimeca para tomar represalias contra los ataques indios, presentando detallada información de la situación de la frontera, 1582, en Powell, 1971: 231. 
busca de otros indios que ni son salteadores ni nos han hecho daño» ${ }^{71}$. En 1574 el oidor Lope de Miranda acusó al gobernador Francisco de Ibarra de haber convertido a la provincia de Chiametla en centro de aprovisionamiento de esclavos para otras regiones ${ }^{72}$. El corolario de esta dilatada situación es que mantener un clima de conflicto era beneficioso para quienes buscaban legitimar la esclavitud indígena.

Frente al hostigamiento sistemático fue inevitable una respuesta igualmente contundente de los indígenas. Aparte de la crítica legal y moral que suscitaban estos incidentes entre religiosos, virreyes y letrados observantes de las leyes, también se elevaron voces de hombres prácticos que ponderaban los inconvenientes de tener que enfrentar las represalias de los nativos, los que solían responder con razias para rescatar a sus mujeres e hijos ${ }^{73}$. Esto, junto a la necesidad de resarcir los agravios recibidos, fueron dos poderosos móviles de las ofensivas chichimecas, cuestión de la que se percataron las mentes más agudas del bando español tras cuatro décadas de lucha. El doctor Juan Bautista de Orozco advirtió al rey que conforme se incrementaba el número de soldados y presidios para el resguardo de las minas, «crecieron asimismo ellos sus cuadrillas de gentes de guerra y comenzaron con furia diabólica a acometer por todas partes y hacer muchos más daños y más crecidos de los que jamás se habían hecho» ${ }^{74}$; el mismo destinatario tuvo el memorial del clérigo Juan Alonso Velázquez, en el cual hizo notar que «estas entradas que los nuestros han hecho en las tierras de estos [chichimecas] han sido muy dañosas pues han hecho más efecto para incitarles a la guerra contra nosotros» $\rangle^{75}$. Lo que es más, las incursiones de castigo solían ser estériles porque los cabecillas chichimecas eran rara vez apresados ${ }^{76}$, captando nuevos adherentes entre las cada vez más numerosas parcialidades disconformes con el trato español.

${ }^{71}$ Relación de Juan Alonso Velázquez, clérigo beneficiado de la villa de San Miguel de los Chichimecas, sobre la guerra con los indios fronteros y los remedios para concluir con ella, 1582, en Assadourian, 2008: 459, 464.

72 Carta de Lope de Miranda a Juan de Ovando, México, 24 de marzo de 1574, AGI, México, 99, f. 6v.

73 Carta del licenciado Alonso Martínez, fiscal de la Real Audiencia de la Nueva Galicia, al presidente Juan de Ovando, Guadalajara, 8 de marzo de 1576, en Enciso Contreras, 1996: 157.

${ }^{74}$ Carta del doctor Orozco, presidente de la Nueva Galicia, al rey, Zacatecas, 28 de septiembre de 1580, en Ibidem: 225.

75 Relación de Juan Alonso Velázquez, clérigo beneficiado de la villa de San Miguel de los Chichimecas, sobre la guerra con los indios fronteros y los remedios para concluir con ella, 1582, en Assadourian, 2008: 463.

76 Carta a Su Majestad de fray Pedro de Ayala, obispo de Nueva Galicia, acerca de la conquista de los chichimecas, Guadalajara, 29 de octubre de 1568, en Orozco y Jiménez, 1926: 362. 
Además, la captura de naturales y su destino como mano de obra forzada envolvía un insospechado riesgo. Cuando el secuestro era de larga duración, tiempo suficiente para interiorizar los problemas y debilidades de la situación española en la región fronteriza, las fugas se convertían en un dilema de trascendencia mayor. La esclavitud podía, por sus inesperadas consecuencias, convertirse en una espada de doble filo, tal como informó al Consejo de Indias el virrey Lorenzo Suárez de Mendoza ${ }^{77}$.

La esclavitud chichimeca, además, cumplía con la función de preservar las alianzas tejidas entre españoles así como entre españoles e indios auxiliares. Con suma frecuencia el éxito de las campañas de conquista y la consolidación del dominio en las regiones del norte requirió de un incentivo económico que, ante la falta de medios, encontró su mejor excusa en la posibilidad de lucrar con la apropiación de la mano de obra nativa. Fray Antonio Tello refiere la situación vivida por Nuño Beltrán de Guzmán en la ciudad de Compostela hacia 1536, cuando pronta a despoblarse por la pobreza e inseguridad en que vivían los vecinos - algunos de los cuales ya se habían mudado a México-, fueron tentados por el gobernador dándoles licencia para hacer esclavos ${ }^{78}$, a pesar de que esto contravenía abiertamente la Real Provisión de $1530^{79}$. Pero la esclavitud no fue solo un anzuelo para inducir la codicia de los españoles, ya que también fue utilizada para mantener la lealtad de los indios aliados. Una década más tarde, en la Guerra del Mixtón, el virrey Antonio de Mendoza entregó a los indios amigos los 248 rebeldes capturados en el peñol de Coyna, a fin de «animallos [sic] a la guerra [...] porque los dichos indios pedían parte» ${ }^{80}$. Dos décadas después, durante la rebelión guachichil-zacateca de principios de la década de 1560, Francisco Sosa, alcalde de la villa de Nombre de Dios, prometió a los aliados mexicanos y tarascos que «al que cojiere a algún chichimecatl [sic] ninguno le quitará, pues será suyo, lo mismo si cojiere a dos o a tres» ${ }^{81}$.

Hasta antes de la conformación del ejército profesional la seguridad de las minas y rutas estaba en manos de los vecinos de las villas y ciudades, por lo que la esclavitud de los nativos rebeldes era uno de los pocos incentivos para

77 Carta del virrey Conde de Coruña al Consejo de Indias sobre la guerra con los indios, México, 13 de enero de 1582, AGI, México, 20.

78 Tello, 1997, cap. LXXV: 230.

79 Ibidem, cap. LXXV: 230 y cap. LIX: 177. El cronista fecha erradamente esta provisión en 1532, tal vez confundiéndola con la Real Cédula para que no se hierren indios esclavos sin licencia real, Medina del Campo, 13 de enero de 1532, en Konetzke, 1953: 138-139.

${ }^{80}$ Fragmento de la visita hecha a don Antonio de Mendoza: Interrogatorio, México, 8 de enero de 1547, en García Icazbalceta, 1866: 113. Véase Altman, 2012: 165-166.

81 Memorial de los indios de Nombre de Dios, Durango, acerca de sus servicios al rey, ca. 1563, en Barlow y Smisor, 1943: 30. 
asegurar la continuidad de los poblados. Cuando el estímulo minero consolidó su preeminencia con el hallazgo del mineral de Zacatecas en 1546, la esclavitud fue vista como un medio válido para reorientar la energía bélica de los chichimecas a las tareas extractivas, premiando así el esfuerzo de quienes se empeñaron en sofocar las revueltas que ponían en riesgo la presencia hispana en las tierras del norte. Por ello no fue una casualidad que pocos años después el oidor Hernán Martínez de la Marcha propusiera al rey que el mejor modo de alcanzar la paz sería «galardonar la gente de guerra haciendo de los más culpados esclavos o a lo menos naborías por voluntad de vuestra majestad [...] Y de esta manera cesarían los daños, muertes y sobresaltos que de cada día tenemos» ${ }^{82}$.

En suma, diversos factores incidieron en la implementación de la violencia española en el territorio de la Nueva Galicia: el deseo de satisfacer ansias de riqueza de hombres que no participaron de la conquista de México y, por lo tanto, que no fueron beneficiados con la repartición de encomiendas; la necesidad de controlar a los grupos nativos y muy especialmente a las movedizas bandas de recolectores-cazadores que recorrían la región; la búsqueda de mano de obra barata que trabajase las minas y las estancias agrícola-ganaderas. La plata de Zacatecas propició una fuerte corriente migratoria de blancos, mestizos y negros esclavos que había que proteger de las acometidas chichimecas y asegurar su sustento. Ante el escaso apoyo económico inicial de la Corona, la esclavitud indígena actuó como una moneda para estimular el interés y retribuir lealtades tanto de españoles como de indios amigos. Los chichimecas, por su parte, tuvieron la habilidad para incorporar elementos del invasor en su propia cultura, fortaleciendo la resistencia e inclinando, en muchas ocasiones, la balanza a su favor: el caballo contribuyó a hacer más eficientes sus correrías en las rutas, estancias, minas y pueblos en que transitaban, laboraban o vivían los cristianos, creando una atmósfera de inseguridad que perduró en gran parte del siglo XVI. Tal situación fue uno de los argumentos más utilizados por los hombres de la espada y la cruz para justificar la esclavitud indígena.

\section{VIOLENCIA ECONÓMICA: IMPACTO ECOLÓGICO, SAQUEOS, ENFERMEDADES Y TRIBUTO}

La mayoría de los testimonios coloniales fundamentan la violencia de los grupos nómadas de la Nueva Galicia en su condición bárbara e idolátrica, pues para la mirada eurocéntrica de los españoles eran gentes de escaso «entendi-

82 Carta del oidor Hernando Martínez de la Marcha a Su Majestad, Compostela, 18 de febrero de 1551, en Assadourian, 2008: 251. 
miento, sutiles para maldades, antes inclinados a mal que a bien ${ }^{83}$. Con excepción de las órdenes regulares, algunos miembros del clero secular y un puñado de oficiales reales, no existió la voluntad de interpretar la falta de colaboración, fugas y violencia indígena como una consecuencia de los atropellos de que eran víctimas. Los agravios eran de índole diversa, excediendo los límites de la vejación física para extenderse al ámbito de la subsistencia. Las primeras entradas de exploración y conquista se caracterizaron por la depredación de los recursos que atesoraban las comunidades productoras de alimentos que se iban cruzando por su derrotero ${ }^{84}$. Si bien en la mayoría de los casos los nativos se mostraron dispuestos a ayudar a los famélicos expedicionarios proporcionándoles recursos de toda índole, una serie de actitudes que atentaban contra el principio de reciprocidad fue socavando la confianza inicial: largas permanencias en los poblados con la consiguiente dilapidación de las reservas, además del atropello a la dignidad de las mujeres y los líderes locales.

En la Nueva Galicia situaciones de esta índole se vivieron desde el más temprano contacto. La entrada de Nuño Beltrán de Guzmán fue una pesada carga para las aldeas nativas que tuvieron que aprovisionar a los españoles y la numerosa comitiva de indios amigos que los secundaban. En el pueblo de Tumala permanecieron quince días siendo aprovisionados «de mucha comida y muchas gallinas de la tierra y de Castilla» ${ }^{85}$, y mientras estuvieron en la provincia de Chiametla los nativos los acogieron en aposentamientos a las afueras del pueblo agasajándolos cada día con «treinta gallinas [...], e dábanles treinta cargas de pescado fresco [...] e mahiz [sic] les daban quanto era menester para todos $\rangle^{86}$. Fray Antonio Tello refiere la situación de Francisco Pentaclatl, cacique de Tzapotzinco, quien huyó de sus tierras por los excesos de Nuño Beltrán de Guzmán, retornando solo cuando el conquistador se marchó a la capital novohispana; casi una década más tarde, y ante nuevos contingentes que reforzaron la posición hispana en las tierras del norte, decidió volver a refugiarse en los montes «pareciéndole que no le había de suceder bien y que le habían de pedir tantas cosas los españoles, que no pudiendo cumplir con ellas, le viniesen a maltratar» ${ }^{87}$.

83 Relación de minas del Fresnillo: Informe de Alonso Tabuyo, minas del Fresnillo, 17 de enero de 1585, en Acuña, 1988: 115.

84 Mathers, 2013: 221-222.

85 Relación sobre la jornada que hizo Nuño de Guzmán, de la entrada y sucesos de la Nueva Galicia, hecha por Pedro de Carranza, en Razo Zaragoza, 1963: 161.

86 Relación hecha a viva voz por el alférez Francisco de Arceo, al capitán e historiador Gonzalo Fernández de Oviedo y Valdés, en Ibidem: 262-263.

87 Tello, 1997, cap. CXIL: 360. 
Los organizadores de excursiones posteriores procuraron avituallar las tropas de los suficientes recursos con el propósito de prevenir circunstancias controversiales que gatillaran rebeliones que amenazaran la frontera, o asaltos que retrasaran y pusieran en riesgo la expedición. Los excedentes para sustentar la tropa y agasajar a los naturales no impidieron, sin embargo, que la rigurosidad de la espada se abriera camino entre las poblaciones reacias a colaborar. Durante la entrada de Nuño Beltrán de Guzmán, cuya hueste iba al principio bien aprovisionada por los tarascos de Michoacán, no solo fueron numerosos los episodios de depredación y despojo, sino también los de desolación después que las viviendas y bodegas de las aldeas se convertían en pasto de las llamas atizadas por los indios amigos. Fue tan habitual la práctica de arrasar las aldeas reticentes a cooperar, que los testigos Pedro de Carranza y Cristóbal Flores coinciden en señalar que «todos los [pueblos] que atrás dejábamos quedaban quemados» ${ }^{88} \mathrm{y}$ «este quemar se continuó siempre por do íbamos ${ }^{89}$. Es muy posible, como afirma Ida Altman, que la costumbre de arrasar la tierra enemiga haya sido de raigambre indígena, siendo incorporada por los conquistadores a su estrategia de control espacial ${ }^{90}$.

Las sociedades productoras de alimentos del norte de la Nueva España no fueron, empero, las únicas víctimas de las exploraciones y asentamientos españoles. La mayoría de las estancias, aldeas y ciudades — con excepción de los enclaves mineros - fueron emplazadas en parajes que detentaban algún grado de fertilidad, cercanos a cursos fluviales, en medio de nichos de aprovisionamiento para grupos nómadas, quedando en adelante vedados a sus circuitos de movilidad. En una verdadera guerra de subsistencia, chichimecas y españoles disputaban los espacios que para unos ostentaban la mayor cantidad de recursos silvestres, y para otros las mejores potencialidades agrícolas y de cría de ganados por la abundancia de pastos. Un ejemplo fue el valle de Valparaíso, situado al norte de las minas de El Peñol, llamado así «por ser muy fértil de agua y pastos, cercado de muchas sierras, lleno de ganados vacunos, deshabitado de gente a causa de la guerra» ${ }^{91}$.

Igualmente determinante fue el impacto de la actividad minera sobre la deforestación de las tierras altas, muy especialmente a partir del auge de

88 Relación sobre la jornada que hizo Nuño de Guzmán, de la entrada y sucesos de la Nueva Galicia, hecha por Pedro de Carranza, en Razo Zaragoza, 1963: 173.

89 Relación de la jornada que hizo Nuño de Guzmán a Nueva Galicia, escrita por el capitán Cristóbal Flores, en Ibidem: 191.

90 Altman, 2012: 158.

91 Relación de minas del Fresnillo: Informe de las minas de El Peñol por Francisco Ruiz, 15 de enero de 1585, en Acuña, 1988: 111. 
Zacatecas a mediados del siglo XVI. La creciente masa de hacendados, peones, mineros y esclavos se valió de las encinas para confeccionar «ejes y ruedas de carretas y carros $\rangle^{92}$, además de «astas de a dos y tres brazas, las cuales les aprovechan de cultivar la tierra con ellas» ${ }^{93}$, y de los robles «para hacer vigas y tablas» ${ }^{94}$. Con pinos y abetos se elaboraban «vigas en las iglesias y casas de su vivienda $\rangle^{95}$. La madera de estos árboles, en especial el ramaje y las sobras del trabajo artesanal y de construcción, era utilizada como leña para abrigar las viviendas. Sin embargo fue la demanda de combustible para las labores de beneficio por el sistema de fundición, asiduamente usado en las primeras décadas, lo que contribuyó primordialmente a desnudar cerros y quebradas para la elaboración de carbón. La depredación forestal llegó a tal extremo que el oidor Francisco de Mendiola expidió un reglamento el 6 de marzo de 1568 para controlar la tala de árboles, poniendo especial énfasis en frenar el trabajo irresponsable e ineficiente que se hacía con las encinas, a las que solían cortar solo las ramas, dejando en los cerros grandes troncos que «no tornan a echar renuevos, antes se secan e pierden ${ }^{96}$. La persistencia del problema llevó al cabildo de Zacatecas a insistir en esta disposición en mayo de $1575^{97}$.

Aunque el posteriormente utilizado sistema de beneficio por mercurio demandaba un menor uso de combustible, se siguió recurriendo a la tala de bosques para el procedimiento de separar por destilación el azogue de la amalgama ${ }^{98}$. José Francisco Román Gutiérrez calcula que para comienzos del siglo XVII casi se había triplicado el radio de deforestación ${ }^{99}$. Evidencia de ello es que hacia 1608 todavía se aprovechaban los ya escasos árboles de los cerros de Zacatecas para producir carbón, y «la madera que se corta es mucha y para el beneficio de las minas se gasta gran cantidad que montará cada año

92 Relación de las minas de San Martín y Llerena, y de su partido, por el alcalde mayor Rodrigo Balcázar, villa y minas de San Martín, 6 de febrero de 1585, en Ibidem: 248.

${ }_{93}$ Relación de la provincia de Tenamaztlán por el Corregidor Pedro de Ávila, 28 de noviembre de 1579, en Ibidem: 285.

${ }^{4}$ Relación de las minas de San Martín y Llerena, y de su partido, por el alcalde mayor Rodrigo Balcázar, villa y minas de San Martín, 6 de febrero de 1585, en Ibidem: 248.

${ }_{95}$ Relación de la provincia de Tenamaztlán por el Corregidor Pedro de Ávila, 28 de noviembre de 1579, en Ibidem: 286.

96 Traslado de las ordenanzas que hizo el señor licenciado don Francisco de Mendiola, minas de Zacatecas, 6 de marzo de 1568, en Fernández Sotelo, 1994: 230.

97 Acta del Cabildo de Zacatecas, 6 de mayo de 1575, Archivo Histórico del Estado de Zacatecas, Zacatecas, México (en adelante AHEZ), Fondo Ayuntamiento, Serie Libros de Cabildo, Primer libro de Cabildo: 51v.

98 Bakewell, 1971: 146.

99 Román Gutiérrez, 2010: 85. 
más de treinta mil pesos» ${ }^{100}$. Casi con resignación el obispo de Guadalajara, Alonso de la Mota Escobar, sentenciaba a comienzos del siglo XVII:

Hauia en su descubrimiento [Zacatecas] mucha arboleda y monte en estas quebradas, las quales todas se an acabado y talado con las fundiciones de manera que si no son vnas palmillas siluestres otra cosa no a quedado. Y ansi es la leña muy cara en esta ciudad porque se trae de ocho y diez leguas en carretas ${ }^{101}$.

Como el sistema de amalgamación no detuvo la tala de árboles la deforestación fue una constante a lo largo del siglo XVI. El nuevo sistema, además, incrementaba la contaminación de suelos y aguas por la toxicidad de los metales pesados desechados, como el mercurio y el plomo. Un agravante no menor fue el uso de la sal, indispensable «para el beneficio de sacar plata por azogue, que sin ella no se podría beneficiar» ${ }^{102}$. Tanto las aguas de arroyos y ríos, como la escasa cubierta orgánica de los suelos circundantes a los puntos de beneficio se veían afectadas por la excesiva salinidad de los fluidos desechados.

En suma, la deforestación de una buena parte de los montes fue resultado de las necesidades económicas de los colonos en su afán por consolidarse en las regiones del norte: el uso creciente de leña para el abrigo y preparación de los alimentos, la confección de utensilios, la construcción de viviendas para una población en ascenso, y el beneficio de los minerales crearon una demanda que solo era satisfecha con la depredación forestal. Esta actividad extractiva, que funcionó prácticamente al margen de un puñado de regulaciones, redujo los recursos silvestres de que se proveían los grupos nómadas y seminómadas a un mínimo. Herederos de una milenaria tradición adaptativa, estas agrupaciones habían desarrollado estructuras sociales y nexos político-económicos intergrupales en consonancia con los sistemas ecológicos en que se desenvolvían, permitiendo una eficiente adaptación al medio, complejo de relaciones políticas, sociales y económicas que Cynthia Radding etiqueta bajo el concepto de Ecología Social ${ }^{103}$. La manipulación no sustentable del ambiente físico, ya sea por agentes internos o foráneos, desestabiliza los sistemas

100 Relacion de Nuestra Señora de los Çacatecas, sacada de la informacion que se hizo por mandado del Consejo, 1608, Biblioteca Nacional de Antropología e Historia, Museo Nacional de Antropología, México D.F. (en adelante BMNAM), caja 26, legajo 30, vol. 2, doc. 74, f. 122.

101 Mota y Escobar, 1966: 63.

102 Relación de las minas de Fresnillo por Juan de Huidobro, minas del Fresnillo, 20 de enero de 1585, en Acuña, 1988: 126.

103 Radding, 1997: 3. 
ecológicos provocando una pérdida de las especies vegetales nativas, una erosión irreversible de los suelos, y la migración o extinción de la fauna local $^{104}$, cambios que obligan a las poblaciones aborígenes a buscar nuevas fuentes de aprovisionamiento y, en casos extremos, a abandonar el territorio. Los chichimecas, viendo limitados sus nichos de abastecimiento, reorientaron sus objetivos de caza y recolección a las estancias ganaderas y agrícolas que surtían a las minas e ingenios. En el momento más álgido de la Guerra Chichimeca era común que los nativos tomaran «muchas vacas y aun yeguas y mulas cuando las pueden haber para comer y para este efecto las llevan la tierra dentro hurtadas y allá tienen ya corrales a nuestro modo donde las encierran y matan» ${ }^{105}$. Lo que los colonos vestían con los ropajes de la malevolencia y la mala inclinación no era más que la consecuencia inevitable de la devastación que ellos mismos habían hecho del medio: con recursos silvestres cada vez más restringidos las bandas de recolectores-cazadores se focalizaron ahora en la adquisición de los bienes domésticos de aquéllos que amenazaban su subsistencia y libertad. La apreciación de Philip Wayne Powell referente a que los guerreros nómadas se sentían tentados por el confort de las vestimentas y el suministro relativamente abundante de carne de los invasores ${ }^{106}$ resulta ser, por lo tanto, insuficiente, ya que desconoce el verdadero trasfondo económico que yacía detrás de las incursiones chichimecas. Sin desconocer a la vendetta, o impulso colectivo por resarcir los agravios recibidos como un importante motor de los ataques indígenas, no pueden obviarse las motivaciones económicas gestadas en el contexto de una economía deprimida por la intervención de terceros. Solo al considerar estas variables es posible comprender en su real dimensión las dificultades que debían enfrentar los colonos al intentar asentarse en los terrenos más fértiles de la región septentrional de la Nueva España: en una verdadera guerra de subsistencia, chichimecas y españoles disputaban los espacios que para unos ostentaban la mayor cantidad de recursos silvestres, y para otros las mejores potencialidades agrícolas y de cría de ganados por la abundancia de pastos.

Pero las embestidas chichimecas no tenían por único objetivo la procuración de recursos, sino también la captura de mujeres que colaboraran en la economía de recolección y muy especialmente con la recuperación demográfica de las bandas. Hernando de Vargas, alcalde mayor de Querétaro, informó

104 Melville, 1997: 9.

105 Relación de Juan Alonso Velázquez, clérigo beneficiado de la villa de San Miguel de los Chichimecas, sobre la guerra con los indios fronteros y los remedios para concluir con ella, 1582, en Assadourian, 2008: 455.

106 Powell, 1947: 308. 
al rey en 1582 de las crueldades que los chichimecas cometían con los prisioneros españoles, negros e indios amigos, destacando que «con las mugeres [sic] parece que tienen alguna misericordia porque las lleban bibas y vsar desto es porque tienen falta dellas» ${ }^{107}$. En todas las sociedades la mujer es la unidad que garantiza tanto la perpetuación del grupo como su integridad cultural: la viabilidad demográfica está condicionada en gran medida por el número de mujeres que detentan las familias o linajes, quienes cumplen además con el importante rol de ser los principales agentes socializadores de las nuevas generaciones. En las agrupaciones que se movilizan constantemente en el espacio cualquier evento que atente considerablemente contra esta fracción de la sociedad — raptos, plagas, matanzas - representaría una amenaza para la preservación del conjunto social. Junto a ello, gran parte de la actividad económica se sustenta sobre el conocimiento que las mujeres tienen de los recursos silvestres, la época y los lugares en que deben recolectarse frutos y raíces, así como el modo adecuado de prepararlos para el consumo. Por lo tanto, una pérdida importante de mujeres conllevaría la extinción irremediable de las agrupaciones de que formaban parte, a menos que se tomen medidas paliativas para superar la crisis, como el rapto de mujeres de otros linajes o etnias. Aunque la evidencia documental es escasa, es posible postular un paralelo entre los chichimecas con la situación vivida por los comanches en la década de 1770, cuando una prolongada sequía y epidemia de viruelas se confabularon para ocasionar un descenso demográfico de grandes proporciones. James Brooks demuestra que la respuesta comanche fue un incremento no solo en el pillaje de ganado, sino también en la captura de mujeres españolas y mestizas a fin de compensar el declive poblacional ${ }^{108}$.

En el noroeste de México las epidemias fueron un aliado silencioso pero igualmente mortífero de las espadas de los conquistadores. La Nueva Galicia y los territorios adyacentes fueron una de las múltiples «tierras vírgenes afectadas por epidemias», tal y como las definiera Alfred Crosby cuatro décadas atrás ${ }^{109}$. Para 1536 fray Antonio Tello calcula que de los indios de Culiacán

107 Descripción de Querétaro por su Alcalde Mayor Hernando de Vargas, Querétaro, 30 de marzo de 1582, en Velázquez, 1897: 21.

108 Brooks, 2002: 68-69. Powell complementa esta apreciación señalando que en un momento del conflicto los chichimecas septentrionales comenzaron a realizar incursiones esclavistas entre los indios de paz para capturar mujeres y niños en la región que mediaba entre Guadalajara y Zacatecas, vendiéndolos a otros grupos situados tierras adentro; véase Powell, 1975: 52.

109 Crosby define a las epidemias de suelos vírgenes como «aquellas en que las poblaciones en situación de riesgo no han tenido ningún contacto previo con las enfermedades que los atacan y por lo tanto están casi inmunológicamente indefensas». Los habitantes del Nuevo 
se habían perdido «ciento y treinta mil, los cuales murieron de sarampión y cámaras de sangre $\rangle^{110}$, hacia 1545 la alta mortandad causada por la peste obligó a levantar hospitales en la Nueva Galicia y Michoacán, en los cuales «entran los indios que enferman, así vecinos como forasteros» ${ }^{111}$, y en 1564 , 1576 y 1588 nuevas plagas asolaron la frontera norte de México con resultados catastróficos. Los datos demográficos de Cook y Borah demuestran claramente la merma poblacional que afectó a la Nueva Galicia en la segunda mitad del siglo XVI, que de 169.721 habitantes en 1548 decayó a apenas 35.300 en $1590^{112}$. Aunque la información se sustenta esencialmente sobre el catastro de aldeas y ciudades (abarcando a la población hispana, negros esclavos e indios encomendados), es plausible extender este descenso demográfico a las agrupaciones nómadas cuando menos hasta cierto grado, ya que su alto rango de movilidad pudo haberlos hecho menos vulnerables al estrago de las pestes ${ }^{113}$. Lo importante a destacar es que la pérdida de mujeres por enfermedades, capturas esclavistas y/o muertes fue un duro golpe para sus economías y estabilidad demográfica, de ahí que el rapto e incorporación al sistema social nómada fuese una forma de compensar las pérdidas.

El último factor de impacto económico fue la imposición de tributos. Los indios de encomienda, así como las parcialidades chichimecas que habían aceptado reducirse voluntariamente al amparo de las colonias otomíes, revestían una importancia fundamental para la seguridad y consolidación de los asentamientos hispanos del norte. Esto, sin embargo, no los libró de ser víctimas de las prácticas características de ese sistema laboral ni de las escondidas pretensiones de los colonos. Los maltratos y privaciones fueron motivo de quejas ante las autoridades ${ }^{114}$, el aliciente para que numerosos «vasallos»

Mundo, producto de su aislamiento geográfico y genético respecto a las poblaciones de los demás continentes, estaban prácticamente indefensos ante enfermedades del Viejo Mundo como la viruela, el sarampión o el tifus, causantes de catástrofes demográficas que alcanzaron niveles extremos en diversas regiones del continente americano. Véase Crosby, 1976: 289. Para un debate, vease Jones, 2003.

110 Tello, 1997: cap. LXXX, 251.

111 Ibidem, cap., CLV: 525.

112 Cook y Borah, 1971: 310. De acuerdo con Susan Deeds, solo en la vecina gobernación de Nueva Vizcaya se calcula que el tifus, la viruela y el sarampión fueron responsables de la muerte del $40 \%$ de la población nativa en la transición del siglo XVI al XVII; véase Deeds, 2003: 15 .

113 Gómez Serrano, 2001: 87, sostiene que mientras en la Nueva España el desplome demográfico alcanzó una proporción de 10 a 1, en la Nueva Galicia parece haberse experimentado una caída menos drástica, con una proporción de 6 a 1 .

114 Un interesante corpus documental del temprano Jalisco deja en claro que sus habitantes recurrieron a las instituciones y autoridades españolas para dejar constancia de los atrope- 
se fugaran a los montes y engrosaran los contingentes de indios rebeldes que asolaban ciudades, haciendas, minas y rutas de tráfico ${ }^{115}$, y en situaciones extremas el acicate para arremeter contra sus propios encomenderos, como sucedió en los días del Mixtón en el pueblo de Xalpa, donde «los naturales dél corrieron á Diego de Proaño, á quien estaban encomendados, y á Diego de Mendoza que estaba con él, y se alzó y se fue el pueblo al monte» ${ }^{116}$. El impacto del tributo fue algo no menor si se tiene presente que la mayoría de las poblaciones nativas de la Nueva Galicia y zonas adyacentes eran sociedades igualitarias, estructuradas originalmente como bandas o tribus de escasa complejidad sociopolítica, que desconocían cualquier forma de contribución. A la sombra del tributo se gestó una práctica insospechada que a pesar de contravenir las normas jurídicas y morales españolas, tomó unas décadas en ser detectada por las autoridades. En la documentación neogalicia se consigna que por «tributarios se entiende en todo este rreyno un yndio casado con mujer e hijos, y da de tributo a Su Magestad seis rreales, una fanega de maíz y una gallina de Castilla, y el soltero o soltera la mitad»117. Los encomenderos solían conminar a los solteros a desposar muchachas que apenas estaban entrando en la pubertad, convencidos de que la productividad per cápita de los adultos (padre y madre) de cada núcleo familiar era mayor que la de las unidades aisladas, puesto que el apremio por cumplir con las cuotas los obligaba a involucrar a sus hijos como fuerza laboral de apoyo. Además, al incitar coactivamente la conformación de matrimonios que en el corto plazo engendrarían hijos, se creaba un desincentivo a las fugas de los indios por la

llos de que eran objeto, véase el documento «Que sepan nuestro sufrimiento»: Xalisco bajo el régimen de la encomienda, ¿1572?, en Calvo et al., 1993: 49-108.

115 Zavala, 1994: 96-97. El doctor Orozco informó al rey en 1580 que los naturales de la provincia de Acaponeta, hasta entonces fieles vasallos del rey, «se habían alzado y rebelado de vuestro real servicio. Y todos juntos a punto de guerra, habían ido a otros pueblos de indios cristianos y muerto muchos de ellos y quemado los pueblos e iglesias, y robado y llevado los ornamentos y campanas y las haciendas de los indios. Que se habían juntado y confederado con los indios chichimecos de la serranía de aquella comarca, y todos juntos, que serían en cantidad de tres o cuatro mil indios, tenían determinado de bajar y destruir toda la provincia y otros pueblos, sus circunvecinos», véase la Carta del doctor Orozco, presidente de la Nueva Galicia, al rey, Zacatecas, 28 de septiembre de 1580, en Enciso Contreras, 1996, 224-225.

116 Fragmento de la visita hecha a don Antonio de Mendoza: Interrogatorio, México, 8 de enero de 1547, en García Icazbalceta, 1866: 104.

117 Relación de los Pueblos de Su Majestad del Nuevo Reyno de Galiçia, y de los yndios tributarios que en ellos ay, y del tributo que pagan y los cargos de Alcaldes Mayores y Corregidores que se proveen, y la juridiçion que cada uno tiene, y de las minas e ciudades, villas y lugares que ay en el distrito del dicho Nuevo Reyno, el pueblo de Analco Tetlán, 1582, BMNAM, caja 26, legajo 30, vol. 2, doc. 2, 11v. 
dificultad de cargar a sus retoños en la hégira. Cuando el rey estuvo al tanto de esto expidió una Cédula Real el 10 de abril de 1581, prohibiendo a los encomenderos que fuercen a «que se casen las indias niñas sin tener edad legítima» ${ }^{118}$, aunque existe constancia que la práctica perduró en el tiempo.

Recapitulando, en esta sección se ha hecho una revaluación de la situación histórica que condicionó por una parte las fugas, y por otra las acometidas chichimecas a los comerciantes e inmigrantes que transitaban por las rutas y senderos del norte de la Nueva España, así como a las estancias y pueblos que se repartían por su abigarrada geografía. En primer lugar, las expediciones exploratorias encabezadas por los capitanes de conquista solían aprovisionarse de las reservas almacenadas por las sociedades sedentarias o semisedentarias que se iban cruzando en su camino, privándolas de una buena parte de los recursos atesorados para enfrentar las épocas de escasez. La respuesta más recurrente de los nativos fue fugarse a los montes y quebradas, donde organizaban las acometidas para recuperar lo perdido a manos de los cristianos. En segundo lugar, la minería de la plata demandaba un suministro constante de leña para el funcionamiento de los hornos de fundición y el proceso de destilación, aprovisionamiento constante que en el mediano plazo trajo como consecuencia la deforestación de una buena parte de los montes circundantes a los centros poblados. Junto a ello, los desechos de sal y mercurio que dejaba el beneficio del mineral barrían con la débil cubierta orgánica de los pocos suelos fértiles de la zona, contaminando ríos y esteros. Este descalabro ecológico afectó a los grupos nómadas y seminómadas de la región, que vieron limitadas muchas de sus principales fuentes de abastecimiento estacional. El resultado inevitable fue la reorientación de los objetivos de caza y recolección de los aborígenes afectados, quienes veían ahora en las caravanas mercantiles, las estancias agrícolas y ganaderas, o los pueblos y minas habitados por españoles un conjunto de fuentes sustitutas de recursos donde proveerse.

Al mismo tiempo, la enfermedades que portaban inconscientemente los españoles y sus indios aliados del sur, así como las capturas esclavistas y muertes de mujeres y niños en acciones punitivas, conllevaron una crisis social y económica en las bandas y tribus chichimecas. Con una economía deprimida por la falta de brazos abocados a las tareas de recolección, y con un potencial demográfico extremadamente limitado por la falta de mujeres, las incursiones que realizaban a lomo de caballo a las estancias y pueblos tenían por objetivo aprovisionarse de las hijas, hermanas y esposas de los indios amigos o de los españoles: ellas reemplazarían la fuerza laboral perdida a

118 Real Cédula prohibiendo a los encomenderos que casen a las niñas indias a la fuerza, Tomar, 10 de abril de 1581, en Tello, 1997, cap. CCXII: 656. 
manos de los cristianos, y permitirían la perpetuación del grupo procreando a los hijos de sus captores.

VIOLENCIA SIMBÓLICA: «DERRIBANDO ÍDOLOS Y LEVANTANDO IGLESIAS»

La violencia ejercida por los europeos no se limitó a mancillar a los indios, apropiarse de su capacidad productiva, enajenar sus bienes y espacios de aprovisionamiento, o desarticular los núcleos familiares con la muerte o esclavitud de hombres, mujeres e infantes. Un aspecto igualmente represor fue el ensañamiento desplegado contra aquellos elementos que consolidaban la integración social de las agrupaciones. Los dispositivos más poderosos eran el culto a los antepasados, los objetos sagrados, y el conjunto de usos y costumbres que reactualizaban la unidad del grupo a lo largo del ciclo anual.

El antropólogo Mircea Eliade, gran conocedor de las formas religiosas del mundo primitivo, destacó que «el hombre de las sociedades arcaicas tiene tendencia a vivir lo más posible en lo sagrado o en la intimidad de los objetos sagrados» ${ }^{119}$. Dichos objetos, y las prácticas asociadas a ellos, constituían uno de los tantos pilares sobre los que descansaba la identidad de esas sociedades, conformándose como un factor de integración grupal. Los españoles, enceguecidos por el dogma de la verdad revelada y azuzados por el espíritu de cruzada con que habían revestido su expansión en el Nuevo Mundo, convirtieron esos elementos sagrados en un objetivo central de su política de extirpación de idolatrías. No debe extrañar, por tanto, que en la Nueva Galicia tanto militares como franciscanos hayan llevado adelante una desenfrenada actividad de búsqueda y destrucción de objetos fetiches. Aunque los datos no son abundantes, son suficientes para esbozar una aproximación al problema. Fray Antonio Tello, inspirado por los prejuicios de su tiempo, describió a los chichimecas como personas que «no tienen leyes, sino que bárbaramente adoran unos ídolos formidables de piedras o barro con diferencias de figuras de animales, a los cuales ofrecen en sacrificio sangre que sacan de sus orejas» ${ }^{120}$. Los ejemplos que brindan las Relaciones Geográficas de la Nueva Galicia son numerosos, revelando que el culto a los ídolos fue una práctica compartida por las sociedades igualitarias y aquellas de mayor complejidad sociopolítica. Antonio de Leiva, alcalde mayor del pueblo de Ameca, refirió en su informe que «los ritos y adoraciones que tenían en su gentilidad era un

119 Eliade, 1998: 15.

120 Tello, 1997, cap. I: 12. 
ídolo de piedra» ${ }^{121}$ al que sacrificaban cautivos capturados en guerra; el teniente de alcalde mayor Lázaro Blanco, al describir a los naturales de Compostela, señala que «ofrecían mantas al ídolo que tenían en cada barrio de señor o pueblo» ${ }^{122}$.

En la documentación de la época es común encontrar la expresión «derribando ídolos y levantando iglesias», explicitando que la implantación de la fe cristiana se hacía sobre la erradicación de las creencias y prácticas paganas precedentes al arribo peninsular a la región. Al referir la actividad misional de fray Juan de Padilla en la provincia de Amula en la década de 1530, Tello dice que el religioso "derribó sus ídolos, [y] erigió templos» ${ }^{123}$, o que ganó almas para Dios «levantando iglesias y derribando ídolos»124. Hombres de armas inspirados por este ideal difusor, como Nuño Beltrán de Guzmán, se valieron de la misma estrategia de barrer idolatrías y levantar iglesias, procurando dejar clara constancia del afán evangelizador que inspiraba sus acciones como una forma de legitimar la exploración y conquista que encabezaban a fuego y espada. El conquistador refirió al rey que las provincias vecinas a la región de Tonalá se confederaron para impedir el avance de la hueste, y que una vez derrotadas en una cruenta batalla librada en la cumbre de un cerro, escogió dicho lugar para levantar «una iglesia muy bonita, que se llama la Victoria de la Cruz, y se puso una cruz de sesenta pies en largo» ${ }^{125}$. Más tarde, cuando arribaron a la región de Xalpa, un grupo de principales se apersonó ante el capitán español, quienes «trugeron ciertos ídolos, los cuales, después de haberles el gobernador hablado, y dicho la vanidad dellos, los mandó quemar en su presencia» ${ }^{126}$. Los nativos le habían señalado que aquellos ídolos eran responsables de la productividad de «sus mahiçales é fresoles é axí é gallinas, é les daban los hijos é mugeres é la ropa y el sol y el agua é todo quanto bien tenían; é les daban la vida é la muerte, quando les placía, e que como á tales dioses é señores suyos los adoraban á acataban é ser-

121 Relación del pueblo de Ameca hecha por Antonio de Leiva, alcalde mayor de Su Majestad, Ameca, 2 de octubre de 1579, en Acuña, 1988: 35.

122 Relacion de la ciudad de Compostela por el teniente Lázaro Blanco, Compostela, 26 de noviembre de 1584, en Ibidem: 91.

123 Tello, 1997, cap. LXVI: 203.

124 Ibidem, cap. CXLVII: 487.

125 Carta a S.M. del Presidente de la Audiencia de Méjico, Nuño de Guzmán, en que refiere la jornada que hizo a Mechoacan, a conquistar la provincia de los Tebles Chichimecas que confina con Nueva España, 1530, en Razo Zaragoza, 1963: 41.

126 Relación del descubrimiento y conquista que se hizo por el gobernador Nuño de Guzmán y su ejército en las provincias de la Nueva Galicia, escrita por Gonzalo López y autorizada por Alonso de Matta, escribano de su Majestad, 1530, en Ibidem: 73. 
vían» ${ }^{127}$. La destrucción veleidosa de elementos sagrados no era una cuestión menor. En medio de una crisis social y económica gestada en el trauma del contacto, el afán revanchista de los naturales, alimentado por la ocupación de sus tierras, la esclavitud indiscriminada y el deterioro de sus ecosistemas, se reforzaba con la pérdida irreparable de los amuletos que amparaban su devenir en el mundo.

La Corona, motivada por cuestiones de índole económica antes que religiosa, fue una férrea impulsora de la confiscación de objetos suntuarios en la Nueva Galicia. En las instrucciones dadas al veedor Bernado Ramírez de Vargas en 1568, se le ordenó que

... todo el oro y plata, piedras preciosas y perlas y otras cosas que se hallaren y hubieren, así en los enterramientos, sepulturas o cúes o templos de indios como en los otros lugares donde solían ofrecer sacrificio a sus ídolos o en otros lugares religiosos, escondidos o enterrados en casa o heredad o tierra o en otra cualquier parte pública o concejil o particular de cualquier estado o dignidad que sea, que de todo ello y de lo demás que de esta calidad se hubiere y hallare, ahora se halle por acaecimiento o buscándolo de propósito, se nos pague la mitad sin descuento de cosa alguna, quedando la otra mitad para la persona que así lo hallare y descubriere ${ }^{128}$.

Casi como un eufemismo, el principio evangelizador actuaba como un velo tras el que se ocultaban los fundamentos económicos de la extirpación, constituyéndose en un medio de legitimación político y moral para transgredir espacios tan sagrados para los naturales como los emplazamientos litúrgicos o los cementerios en que descansaban sus ancestros. El paso del paganismo a la incorporación de los preceptos de la fe cristiana fue una experiencia tan violenta como el castigo físico o la ocupación de sus tierras.

\section{CONCLUSIÓN}

A lo largo del siglo XVI el extremo norte de la Nueva España fue un escenario de sensaciones y acontecimientos encontrados: las cambiantes circunstancias que definieron la relación interétnica por poco más de media centuria determinaron que las esperanzas y frustraciones, los anhelos y desilusiones se mantuvieran en un precario equilibrio. La tinta con que se escri-

127 Relación hecha de viva voz por el alférez Francisco de Arceo, al capitán e historiador Gonzalo Fernández de Oviedo y Valdés, 1535, en Ibidem: 252.

128 Instrucción de factor y veedor a don Bernardo Ramírez de Vargas, Madrid, 19 de mayo de 1568, en Enciso Contreras, 1998: 234. 
bieron las primeras páginas de la historia de la Nueva Galicia fue la sangre de hombres y mujeres nativos, españoles y mestizos que protagonizaron ese choque cultural, el que habría de marcar la tónica de las futuras zonas fronterizas del continente. Como lo definiera Philip Wayne Powell, ese territorio septentrional fue la primera frontera hispano-indígena del continente, y en tal condición se constituyó en un modelo para venideras políticas de control en otros espacios de interacción. Es por esto que el estudio y clasificación de las modalidades de control espacial y humano implementadas por los hombres de la espada y la cruz es un primer paso para futuros estudios comparativos.

Las sucesivas expediciones que atravesaron sus planicies, ríos, montes y quebradas estuvieron impulsadas por motivaciones arraigadas en la fantasía y la realidad: lugares míticos como el poblado de las Amazonas o las ciudades de Cíbola se entrecruzaron con el hallazgo de ricas vetas de plata, creando un poderoso imán de atracción que se mantuvo vigente durante gran parte de la época colonial. Similares alicientes tuvieron las exploraciones a la Sierra de la Plata en el siglo XVI, o a la Patagonia en los siglos XVII y XVIII, donde los rumores hablaban de un reino de oro y plata anclado en las montañas, o de la ciudad de los Césares en las latitudes australes: ambas historias, que corrían de boca en boca, obnubilaron el entendimiento de gobernadores y soldados, ansiosos por dar con su paradero. El paso de la emocionalidad barroca a la racionalidad ilustrada no desvaneció las utopías que cargaba la mente del hombre occidental venido a las Américas o criado en ellas, ya que los remotos y recónditos espacios de frontera fueron el refugio ideal para las quimeras y los mitos.

En la Nueva Galicia el afán de numerosos españoles y mestizos por labrarse un lugar en el mundo, insertos en un teatro de contradicciones en el que los anhelos se estrellaron contra una geografía desafiante y poblaciones reacias a la sumisión, incentivó una tensa relación de violencia y contraviolencia que puso a prueba el proyecto hegemónico peninsular. A pesar de que en las pioneras zonas del Caribe y el valle de México la consolidación del dominio español no fue ajena a los actos de intimidación, las semiáridas tierras del noroeste fueron el marco de un dilatado conflicto en el que se pusieron a prueba viejas estrategias y se ensayaron nuevos dispositivos de poder. No fue así una novedad mutilar a los indios alzados o convertir a los rebeldes en mano de obra esclava, tal y como había ocurrido con los arawakos caribeños. Mucho menos lo fue el empleo de indios aliados para asegurar la victoria en batallas y consolidar posteriormente el control sobre las poblaciones vencidas, como sucedió con los tlaxcaltecas en México central. Lo que ciertamente representó una novedad fue el empleo primero de otomíes y después de tlaxcaltecas como «indios madrineros», vale decir como pedagogos nativos 
que sirviesen a los chichimecas recién reducidos de ejemplo de obediencia y cristiandad ${ }^{129}$. También destacó el uso generalizado de fortalezas para asegurar las comunicaciones entre las ciudades y pueblos fronterizos con el corazón del Virreinato, llegando a constituirse un ejército profesional que asegurara el paso de caravanas y diese resguardo a la labor de los misioneros en las reducciones. Apenas iniciado el siglo XVII la difícil situación de los colonos en la frontera mapuche de la Capitanía General de Chile obligó, igualmente, a implementar el sistema de fuertes y a organizar un ejército profesional pagado por el Virreinato del Perú. No fue, sin embargo, el hallazgo de vetas mineras lo que impulsó esta política de dominio en las latitudes australes del Imperio Español, sino el temor a que los indios rebeldes traspasaran el límite fronterizo poniendo en riesgo las ciudades de más al norte, y a que se consolidara en esas regiones indómitas un enclave de avanzada holandés o inglés que pactara con los naturales. Casi al mismo tiempo los jesuitas proyectaron la implementación de un sistema de Guerra Defensiva, muy similar a aquél que los franciscanos ayudaron a desplegar en la Nueva Galicia después del Tercer Concilio Provincial Mexicano poco más de un cuarto de siglo antes. Paradójico resulta, sin embargo, que haya sido un sacerdote franciscano, fray Pedro de Sosa, quien se opuso en la corte de Madrid al establecimiento del nuevo sistema de pacificación entre los indios de Chile, argumentando que la naturaleza de ese conflicto distaba en demasía de lo sucedido décadas atrás en las latitudes septentrionales del Imperio Español ${ }^{130}$. De esta manera, ya sea para adoptar o rechazar las medidas obradas, la experiencia chichimeca estuvo presente en la discusión sobre el mejor modo de acabar con el conflicto mapuche. Las crisis de las fronteras españolas en el Nuevo Mundo estuvieron condicionadas por factores diversos, frente a los cuales se desplegaron similares medidas de apaciguamiento. La dinámica del ensayo y error mostró que una solución exitosa en un rincón del imperio podía fructificar o fracasar rotundamente en otra de sus regiones.

Los chichimecas fueron los primeros nativos del continente en hacer un uso extensivo del caballo para sus incursiones predadoras en pueblos, haciendas y minas hispanas. Una experiencia similar vivenciaron los asentamientos peninsulares de otras latitudes, como ocurrió con los guaraníes del Paraguay, los guaycurúes del Chaco, y los mapuches de las pampas ríoplatenses, quienes también alcanzaron un total dominio de este animal para sus incursiones. La cultura de los «salvajes» siempre manifestó una alta capacidad para incorpo-

129 Sheridan, 2001: 27.

130 Memorial de fray Pedro de Sosa del peligroso estado espiritual y temporal del Reyno de Chile, ¿1616?, en Medina, 1898: 173-174, 177-178. 
rar y adaptar los medios del invasor para sus propios fines. A su favor jugaba el perfecto conocimiento de la geografía en que desenvolvían sus operaciones.

Éstas y otras situaciones dejan en evidencia que la frontera chichimeca fue un preámbulo de futuras coyunturas de conflicto interétnico. Delinear las motivaciones y características de la colonización española en la Nueva Galicia es una puerta que permite abrir espacios de reflexión histórica, como la circulación de experiencias en un sistema imperial. El fracaso de las medidas represivas llevadas adelante «a fuego y sangre» dio por resultado la implementación de una política misional que, a la larga, mostró frutos mucho más promisorios. La labor franciscana de pacificación de los chichimecas desplegada a partir de 1585 es una temática ajena a los intereses de este artículo, pero indagar en el modo en que dicha actividad incidió en otras regiones del continente es tarea de una futura investigación.

\section{BIBLIOGRAFÍA}

Acuña, René (ed.), Relaciones geográficas del siglo XVI: Nueva Galicia, México D.F., Universidad Nacional Autónoma de México, 1988.

Adorno, Rolena, «Peaceful conquest and law in the Relación (Account) of Alvar Núñez Cabeza de Vaca», Francisco Javier Cevallos-Candau, Jeffrey A. Cole, Nina M. Scott y Nicomedes Suárez Arauz (eds.), Coded Encounters: writing, gender, and ethnicity in colonial Latin America, Amherst, University of Massachussetts Press, 1994: 75-86.

Altman, Ida, «Conquest, coercion, and collaboration: Indian allies and the campaigns in Nueva Galicia», Laura E. Matthew y Michael R. Oudijk (eds.), Indian Conquistadors: indigenous allies in the conquest of Mesoamerica, Norman, University of Oklahoma Press, 2012: 145-174, $2^{\mathrm{a}}$ ed.

Armillas, Pedro, «The arid frontier of Mexican civilization», Transactions of the New York Academy of Sciences, segunda serie, 31/6 (1969): 697-704.

Arnal, Luis, «El Presidio. Instrumento de población en el septentrión novohispano», Salvador Bernabéu Albert (coord.), Poblar la inmensidad: sociedades, conflictividad y representación en los márgenes del Imperio Hispánico (siglos XV-XIX), Madrid, CSIC/Ediciones Rubeo, 2010: 107-128.

Assadourian, Carlos Sempat (ed.), Zacatecas. Conquista y transformación de la frontera en el siglo XVI: minas de plata, guerra y evangelización, México D.F., El Colegio de México, 2008.

Bakewell, Peter, Silver mining and society in Colonial Mexico, Zacatecas 1546-1700, Cambridge, Cambridge University Press, 1971. 
Barlow, Robert H. y Smisor, George T., Nombre de Dios, Durango. Two documents in Nahuatl concerning its foundation, Sacramento, The House of Tlaloc, 1943.

Barral Gómez, Ángel, Rebeliones indígenas en la América española, Madrid, Editorial Mapfre, 1992.

Beals, Ralph, Etnohistoria del noroeste de México, México D.F., El Colegio de Sinaloa/Consejo Nacional para la Cultura y las Artes/Instituto Nacional de Antropología e Historia/Siglo XXI Editores, 2011, vol. 1.

Blackhawk, Ned, Violence over the Land. Indians and Empires in the early American West, Cambridge, Harvard University Press, 2006.

Braniff, Beatriz, «Oscilación de la frontera septentrional Mesoamericana», Betty Bell (ed.), The archaeology of West Mexico, Jalisco, Sociedad de Estudios Avanzados del Occidente de México, 1974: 40-50, $2^{\mathrm{a}}$ ed.

Braniff, Beatriz, «The Mesoamerican Northern Frontier and the Gran Chichimeca», Anne I. Woosley y John C. Ravesloot (eds.), Culture and contact: Charles C. Di Peso's Gran Chichimeca, Dragoon, Amerind Foundation Publication, 1993: 65-82.

Braniff, Beatriz. «Introducción», Beatriz Braniff(ed.), La Gran Chichimeca. El lugar de las rocas secas, México D.F., Consejo Nacional para la Cultura y las Artes/ Editorial Jaca Book, 2001: 7-12.

Brooks, James, Captives and cousins. Slavery, kinship, and community in the southwest borderlands, Chapel Hill, University of North Carolina Press, 2002.

Calvo, Thomas, La Nueva Galicia en los siglos XVI y XVII, Guadalajara, Centro de Estudios Mexicanos y Centroamericanos/El Colegio de Jalisco, 1989.

Calvo, Thomas, Celestino, Eustaquio, Gómez, Magdalena, Meyer, Jean y Xochitemol, Ricardo (eds.), Xalisco, la voz de un pueblo en el siglo XVI, México D.F., Ciesas/Centro de Estudios Mexicanos y Centroamericanos, 1993.

Carrillo Cázares, Alberto, «La congregación de pueblos en la frontera chichimeca», Relaciones: Estudios de historia y sociedad, 108/XXVII (Zamora, 2006): 125-137.

Chavero, Alfredo (ed.), El Lienzo de Tlaxcala, México D.F., Editorial Cosmos, 1979.

Chevalier, Françoise, La formación de los latifundios en México: haciendas y sociedad en los siglos XVI, XVII y XVIII, México D.F., Fondo de Cultura Económica, $1999,2^{\mathrm{a}}$ ed.

Cisneros Guerrero, Gabriela, «Cambios en la frontera chichimeca en la región centro-norte de la Nueva España durante el siglo XVI», Investigaciones Geográficas, 36 (México D.F., 1998): 57-70.

Colin, Susi, «The Wild Man and the Indian in early 16th century book Illustration», Christian F. Feest (ed.), Indians \& Europeans. An interdisciplinary collection of essays, Lincoln, University of Nebraska Press, 1999: 5-36, $2^{\mathrm{a}}$ ed. 
Cook, Sherburne F. y Borah, Woodrow, Essays in Population History: Mexico and the Caribbean, Berkeley, University of California Press, 1971, vol. I.

Cramaussel, Chantal, «De cómo los españoles clasificaban a los indios. Naciones y encomiendas en la Nueva Vizcaya central», Marie-Areti Hers, José Luis Mirafuentes, María de los Dolores Soto y Miguel Vallebueno (eds.), Nómadas y sedentarios en el norte de México. Homenaje a Beatriz Braniff, México D.F., Universidad Nacional Autónoma de México, 2000: 275-303.

Cramaussel, Chantal, «El camino real de tierra adentro. De México a Santa Fe», Chantal Cramaussel (ed.), Rutas de la Nueva España, Zamora, El Colegio de Michoacán, 2006: 299-327.

Crosby, Alfred W., «Virgin soil epidemics as a factor in the Aboriginal depopulation in America», The William and Mary Quarterly, 33/2 (Williamsburg, 1976): 289-299.

Cruz Rangel, José Antonio, Chichimecas, mineros, soldados y terratenientes. Estrategias de colonización, control y poder en Querétaro y la Sierra Gorda. Siglos XVI-XVIII, México D.F., Archivo General de la Nación, 2003.

Deeds, Susan M., Defiance and deference in Mexico's colonial north: Indians under Spanish rule in Nueva Vizcaya, Austin, University of Texas Press, 2003.

Di Peso, Charles, Casas Grandes. A fallen trading center of the Gran Chichimeca, Dragoon, The Amerind Foundation/Northland Press, 1974, vol. 1.

Eliade, Mircea, Lo Sagrado y lo Profano, Barcelona, Paidós, 1998.

Enciso Contreras, José (ed.), Epistolario de Zacatecas, 1549-1599, Zacatecas, Ediciones del Ayuntamiento de Zacatecas, 1996.

Enciso Contreras, José (ed.), Cedulario de Zacatecas, 1554-1596, Zacatecas, Ayuntamiento de Zacatecas/Ayuntamiento de Oñati/Facultad de Derecho de la Universidad Autónoma de Zacatecas, 1998.

Faulk, Odie B., «El presidio: ¿fuerte o farsa?», David Weber (ed.), El México perdido. Ensayos escogidos sobre el antiguo norte de México, 1540-1821, México D.F., Septentas, 1976: 55-67.

Fernández Sotelo, Rafael Diego (ed.), La primigenia Audiencia de la Nueva Galicia, 1548-1572: respuesta al cuestionario de Juan de Ovando por el oidor Miguel Contreras y Guevara, Zamora, El Colegio de Michoacán, 1994.

García Icazbalceta, Joaquín, Colección de documentos para la historia de México, México D.F, Antigua Librería Portal de Agustinos, 1866, tomo 2.

Gómez Serrano, Jesús, Guerra Chichimeca, la fundación de Aguascalientes y el exterminio de la población aborigen, 1548-1620. Un ensayo de reinterpretación, Jalisco, El Colegio de Jalisco, 2001.

González Rodríguez, Jaime, La idea de Roma en la historiografía indiana (14921550), Madrid, CSIC, Instituto «Gonzalo Fernández de Oviedo», 1981. 
Hackett, Charles Wilson (ed.), Historical documents relating to New Mexico, Nueva Vizcaya, and approaches thereto, to 1773, Washington D.C., Carnegie Institution of Washington, 1923, vol. I.

Herrera y Tordesillas, Antonio de, Historia General de los hechos de los Castellanos en las Islas y Tierra Firme del Mar Océano, Madrid, Imprenta y Editorial Maestre, 1953 [1601-1615], vol. 12.

Hers, Marie-Areti, «La sombra de los desconocidos: los no mesoamericanos en los confines tolteca-chichimecas»,, Beatriz Braniff (ed.), La Gran Chichimeca. El lugar de las rocas secas, México D.F., Consejo Nacional para la Cultura y las Artes/Editorial Jaca Book, 2001: 65-70.

Jiménez, Alfredo, El Gran Norte de México. Una frontera imperial en la Nueva España (1540-1820), Madrid, Editorial Tebar, 2006.

Jiménez Moreno, Wigberto, «Tribus e idiomas del Norte de México», El norte de México y el sur de Estados Unidos. Tercera reunión de mesa redonda sobre problemas antropológicos de México y Centro América, Castillo de Chapultepec, 25 de agosto a 2 de septiembre de 1943, México D.F., Sociedad Mexicana de Antropología, 1944: 121-133.

Jones, David S., «Virgin soils revisited», The William and Mary Quarterly, 60/4 (Williamsburg, 2003): 703-742.

Jones, Kristine L., «Comparative raiding economies, North and South», Donna J. Guy y Thomas E. Sheridan (eds.), Contested Ground. Comparative frontiers on the Northern and Southern edges of the Spanish Empire, Tucson, The University of Arizona Press, 1998.

Kirchoff, Paul, «Mesoamérica, sus límites geográficos, composición étnica y caracteres culturales», Acta Americana 1/1 (México D.F., 1943): 92-107.

Kirchoff, Paul, «Los recolectores-cazadores del norte de México», El norte de México y el sur de Estados Unidos. Tercera reunión de mesa redonda sobre problemas antropológicos de México y Centro América. Castillo de Chapultepec, 25 de agosto a 2 de septiembre de 1943, México D.F., Sociedad Mexicana de Antropología, 1944: 133-144.

Konetzke, Richard, Colección de documentos para la historia de la formación social de Hispanoamérica, 1493-1810, Madrid, CSIC, 1953, vol. I.

Las Casas, Bartolomé de, Breve relación de la destrucción de las Indias Occidentales, México D.F., Libros Luciérnaga, 1957 [1552].

Lázaro Ávila, Carlos, Las fronteras de América y los «Flandes Indianos», Madrid, CSIC, 1997.

Leonard, Irving, «Conquerors and Amazons in Mexico», Hispanic American Historical Review, 24/4 (Durham, 1944): 561-579. 
Leonard, Irving, Books of the brave, being an account of books and of men in the Spanish conquest and settlement of the sixteenth-century New World, Cambridge, Harvard University Press, 1949.

Levin Rojo, Danna A., Return to Aztlan: Indians, Spaniards, and the invention of Nuevo México, Norman, University of Oklahoma Press, 2014.

López-Portillo y Weber, José, La conquista de la Nueva Galicia, México D.F., Talleres Gráficos de la Nación, 1935.

López-Portillo y Weber, José, La rebelión de la Nueva Galicia, México D.F., E. Murgia, 1939.

Marimán, Pablo, Caniuqueo, Sergio, Millalén, José y Levil, Rodrigo, i...Escucha, winka...! Cuatro ensayos de Historia Nacional Mapuche y un epílogo sobre el futuro, Santiago de Chile, LOM Ediciones, 2006.

Mathers, Clay, «Contest and violence on the Northern borderlands frontier. Patterns of Native-European conflict in the sixteenth-century Southwest», Clay Mathers, Jeffrey M. Mitchen y Charles M. Haecker (eds.), Native and Spanish New Worlds: Sixteenth-century entradas in the American Southwest and Southeast, Tucson, The University of Arizona Press, 2013: 205-230.

McEnroe, Sean F., From colony to nationhood in Mexico: laying the foundations, 1560-1840, New York, Cambridge University Press, 2014, $2^{\mathrm{a}}$ ed.

Medina, José Toribio, Biblioteca Hispano Chilena, Santiago de Chile, Impreso y grabado en casa del autor, 1898, tomo II.

Melville, Elinor G. K., A plague of sheep. Environmental consequences of the Conquest of Mexico, New York, Cambridge University Press, 1997, $2^{\mathrm{a}}$ ed.

Montoto, Santiago (ed.), Colección de documentos inéditos para la historia de Ibero-América, Madrid, Editorial Ibero-Africano-Americana, 1927, tomo I.

Mota y Escobar, Alonso de la, Descripción geográfica de los Reynos de Nueva Galicia, Nueva Vizcaya y Nuevo León, Guadalajara, Instituto Jalisciense de Antropología e Historia/INAH, 1966 [1605].

Nárez, Jesús, «Aridamérica y Oasisamérica», Historia Antigua de México, sus áreas culturales, los orígenes y el horizonte Preclásico, Linda Manzanilla y Leonardo López Luján (coords.), México D.F., Instituto Nacional de Antropología e Historia/ Universidad Nacional Autónoma de México/Grupo Editorial Miguel Ángel Porrúa, 2000: 121-157, vol. I, $2^{\mathrm{a}}$ ed.

Núñez Cabeza de Vaca, Alvar, Naufragios y Comentarios, Buenos Aires, Calpe, 1922 [1555].

Orozco y Jiménez, Francisco, Colección de documentos históricos, inéditos o muy raros, referentes al Arzobispado de Guadalajara, Guadalajara, Tipografía y Litografía sucesores de Loreto y Ancira, 1922, vol. I. 
Orozco y Jiménez, Francisco, Colección de documentos históricos, inéditos y muy raros, referentes al Arzobispado de Guadalajara, Guadalajara, Litografía Industrial-Imprenta Artística, 1926, tomo V, n. ${ }^{\circ} 1$.

Othón de Mendizábal, Miguel, «Colonización del oriente de Jalisco y Zacatecas», El norte de México y el sur de Estados Unidos. Tercera reunión de mesa redonda sobre problemas antropológicos de México y Centro América, Castillo de Chapultepec, 25 de agosto a 2 de septiembre de 1943, México D.F., Sociedad Mexicana de Antropología, 1944: 40-49.

Parker, Geoffrey, The Army of Flanders and the Spanish road, Cambridge, Cambridge University Press, 1972.

Parker, Geoffrey, Empire, war and faith in early modern Europe, London, Penguin, 2002.

Paso y Troncoso, Francisco del (ed.), Epistolario de Nueva España, 1505-1818, México D.F., Antigua Librería Robredo de José Porrúa e hijos, 1939, tomo II.

Powell, Philip Wayne, «Presidios and towns on the Silver Frontier of New Spain, 15501580», Hispanic American Historical Review, 24/2 (Durham, 1944a): 179-200.

Powell, Philip Wayne, «Spanish warfare against the Chichimecas in the 1570's», Hispanic American Historical Review, 24/4 (Durham, 1944b): 580-604.

Powell, Philip Wayne, «The Chichimecas: Scourge of the Silver Frontier in sixteenth-century Mexico», Hispanic American Historical Review, 25/3 (Durham, 1945): $315-338$.

Powell, Philip Wayne, «Franciscans on the Silver Frontier of Old Mexico», The Americas, 3/3 (Cambridge, 1947): 295-310.

Powell, Philip Wayne, «The Forty-Niners of sixteenth-century Mexico», Pacific Historical Review, 19/3 (Oakland, 1950): 235-249.

Powell, Philip Wayne, «Portrait of an American Viceroy: Martín Enríquez, 15681583», The Americas, 14/1 (Cambridge, 1957): 1-24.

Powell, Philip Wayne, War and Peace on the north Mexican frontier: a documentary record, Madrid, Ediciones José Porrúa Turanzas, 1971.

Powell, Philip Wayne, Soldiers, Indians and Silver. North America's first frontier war, Tempe, Center for Latin American Studies, Arizona State University, 1975, $3^{\text {a }}$ ed.

Powell, Philip Wayne, «Genesis of the Frontier Presidio in North America», Western Historical Quarterly, 13/2 (Logan, 1982): 125-141.

Powell, Philip Wayne, «North America’s first frontier, 1546-1603», George Wolfski11 y Stanley Palmer (eds.), Essays on Frontiers in World History, College Station, Texas A \& M University Press, 1983: 12-41.

Radding, Cynthia, Wandering Peoples. Colonialism, ethnic spaces, and ecological frontiers in Northwestern Mexico, 1700-1850, Durham, Duke University Press, 1997. 
Razo Zaragoza, José Luis (ed.), Crónicas de la conquista del Nuevo Reyno de Galicia, Guadalajara, Instituto Jaliscience de Antropología e Historia, 1963.

Román Gutiérrez, José Francisco, Sociedad y evangelización en la Nueva Galicia durante el siglo XVI, Guadalajara, Instituto Nacional de Antropología e Historia/ El Colegio de Jalisco/Universidad Autónoma de Zacatecas, 1993.

Román Gutiérrez, José Francisco, «La frontera biológica en el Nuevo Mundo», José Francisco Román Gutiérrez y Leticia Ivonne del Río (coords.), Población, frontera, cultura y desarrollo: aproximaciones desde la historia, Zacatecas, Universidad Autónoma de Zacatecas, 2010: 45-105.

Sauer, Carl, Aztatlán, México D.F., Siglo Veintiuno Editores, 1998.

Sescosse, Federico, «Zacatecas en 1550», Artes de México, 194-195 (México D.F., 1960): 4-9.

Sheridan, Cecilia, "“Indios Madrineros”. Colonizadores tlaxcaltecas en el noreste novohispano», Estudios de Historia Novohispana, 24 (México D.F., 2001): 15-51.

Sheridan, Thomas E., "The limits of power: the political ecology of the Spanish Empire in the Greater Southwest», Antiquity, 66 (Tucson, 1992): 153-171.

Tello, Fray Antonio, Libro Segundo de la Crónica Miscelánea, en que se trata de la conquista espiritual y temporal de la Santa Provincia de Xalisco en el Nuevo Reino de la Galicia y Nueva Vizcaya y descubrimiento del Nuevo México, México D.F., Editorial Porrúa, 1997 [1653].

Tenamaztle, Francisco, Relación de los agravios hechos por Nuño de Guzmán y sus huestes a don Francisco Tenamaztle, México D.F., Siglo XXI Ediciones, 1959 [1555].

Torre Villar, Ernesto de la y Navarro de Anda, Ramiro (eds.), Instrucciones y Memorias de los Virreyes Novohispanos, México D.F., Editorial Porrúa, 1991, vol. I.

VV.AA., Cartas de Indias, México D.F., Grupo Editorial Miguel Ángel Porrúa, 1877.

Velázquez, Primo Feliciano, Colección de documentos para la historia de San Luis Potosí, San Luis Potosí, Imprenta del Editor, 1897, tomo I.

Weber, David J., Bárbaros: Spaniards and their savages in the Age of Enlightenment, New Haven, Yale University Press, 2005.

Wright-Carr, David Charles, Conquistadores otomíes en la Guerra Chichimeca, Querétaro, Talleres Gráficos del Gobierno del Estado de Querétaro, 1988.

Wright-Carr, David Charles, La conquista del Bajío y los orígenes de San Miguel de Allende, México D.F., Editorial de la Universidad del Valle de México/Fondo de Cultura Económica, 1999.

Zavala, Silvio, «Los esclavos indios en el norte de México, siglo XVI», El norte de México y el sur de Estados Unidos. Tercera reunión de mesa redonda sobre problemas antropológicos de México y Centro América. Castillo de Chapultepec, 25 
de agosto a 2 de septiembre de 1943, México D.F., Sociedad Mexicana de Antropología, 1944: 83-118.

Zavala, Silvio, Los esclavos indios en Nueva España, México D.F., El Colegio Nacional, 1967.

Zorita, Alonso, Cedulario de 1574, México D.F., Miguel Ángel Porrúa, 1985 [1574].

Fecha de recepción: 28 de marzo de 2016.

Fecha de envío de las modificaciones: 14 de julio de 2016.

Fecha de aceptación: 15 de julio de 2016.

\section{Dynamics of Hispano-indigenous confrontation in the Kingdom of New Galicia and adjacent regions, sixteenth century}

The aim of this work is to reveal the factors that influenced the origin and duration of the Chichimeca War between natives and Spaniards in the New Galicia region during the sixteenth century. I propose a classification of Spanish actions, considering their interests and needs, and an interpretation of how these factors gave rise to the first continental borderland of the New World. Measures implemented in this interethnic conflict were a landmark in the development and deployment of border policies in other regions of America.

Key words: Chichimeca War; New Galicia; conquest of America; interethnic violence; New World borderlands. 